\title{
Conservação e restauro do patrimônio geológico e sua relevância para a geoconservação
}

\author{
Conservation and restoration of geological heritage and its relevance to geoconservation \\ KÁTIA LEITE MANSUR, LUIZA CORRAL MARTINS DE OLIVEIRA PONCIANO, \\ ALINE ROCHA DE SOUZA FERREIRA DE CASTRO, ISMAR DE SOUZA CARVALHO \\ Universidade Federal do Rio de Janeiro - katia@geologia.ufrj.br - luizaponciano@gmail.com - aline@geologia.ufrj.br - \\ ismar@geologia.ufrj.br
}

\begin{abstract}
Resumo
O desenvolvimento e adaptação de metodologias e diretrizes específicas para a conservação e o restauro do patrimônio geológico in situ e ex situ são temas relevantes para as ações voltadas para a Geoconservação. A fim de contribuir para o desenvolvimento desta área, foram analisadas intervenções em monumentos e geossítios brasileiros e internacionais, visando sua preservação frente às ameaças naturais ou antrópicas. Algumas medidas de conservação e restauro podem deteriorar o valor científico, didático e estético dos geossítios, quando não é realizado um planejamento adequado e análise crítica prévia. São sugeridas algumas ações práticas para o controle da erosão e outros efeitos do intemperismo, o restauro de geossítios danificados por vandalismo e a realização de projetos de educação patrimonial, incluindo a participação de profissionais de diversas áreas para consolidar novos métodos de preservação do patrimônio geológico.
\end{abstract}

Palavras-chave: Geoconservação, Restauro, Educação Patrimonial, Patrimônio Geológico.

\begin{abstract}
This paper aims to highlight the necessity to develop and adapt methodologies and guidelines to conservation and restoration of the in situ and ex situ geological heritage. At the moment, these issues have been superficially discussed in the available literature on Geoconservation in Brazil. The interventions in national and international monuments and geosites were analyzed in form to contribute to their preservation against natural and anthropogenic threats. Some conservation and restoration technics can damage the aesthetic, scientific and didactic value of the geosites, if the responsible for its protection doesn't make planning and critical analysis of the interventions. It is suggested practical actions to erosion control and other weathering effects, to the restoration of geosites damaged by vandalism and to the implementation of projects of heritage education. It is important too, the participation of professionals of several knowledge areas to consolidate news approaches to the preservation of geological heritage.
\end{abstract}

Key words: Geoconservation, Restoration, Heritage Education, Geoheritage.

\section{INTRODUÇÃO}

Com base na análise das várias formas de proteção do patrimônio cultural, Flores (2005) define Preservação como todas as ações que beneficiam a manutenção do bem cultural, incorporando, inclusive, a legislação. Conservação é o conjunto de medidas destinado a conter as deteriorações de um objeto ou resguardá-lo de danos. Restauração é o trabalho de recuperação feito em construção ou em objeto parcialmente destruído ou é a intervenção que se realiza num objeto com a finalidade de recompô-lo. Para Flores (2011) a conservação visa interromper os processos de deterioração, conferindo estabilidade à obra, enquanto a restauração atua sobre um objeto para não apenas conferir-lhe estabilidade, mas recuperar, ao máximo possível, as informações nele contidas. Todas estas definições foram apropriadas de análises sobre os bens culturais e conclui-se que a preservação envolve a conservação (prevenção ou manutenção) e a restauração (recuperação) (Mansur 2011). A compreensão destes conceitos pode variar de acordo com a área em que são utilizados. Para o patrimônio geológico, no entanto, parecem perfeitamente aplicáveis. Destaca-se que o patrimônio paleontológico está incluso nesta análise.

O patrimônio cultural conta com a preocupação sistemática para sua proteção desde a Revolução Francesa, com a tomada de consciência após a destruição de bens artístico- culturais e a decisão de restaurá-los, além da expropriação dos bens do clero, dos imigrados e da monarquia, o que configura, inclusive, o valor público do patrimônio (Choay 2001).

Segundo Gonçalves (2002), é a distância espacial ou temporal em relação àquilo que os bens significam que os faz desejáveis e, consequentemente, alvo das práticas de apropriação, restauração e preservação. Enquanto significantes, esses objetos são usados para significar uma realidade que jamais poderá ser trazida por eles, uma realidade que será, como todo objeto de desejo, para sempre ausente. As práticas de apropriação, restauração e preservação desses objetos 
são estruturalmente articuladas por um desejo "permanente e insaciável" pela autenticidade, que é o efeito de sua própria perda. O restauro possui uma Carta Patrimonial específica (Cury 2000), a Carta de Veneza, de 1964, sobre a conservação e a restauração de monumentos e sítios, embora o tema seja tratado desde a Carta de Atenas, de 1931, que foi a primeira a ser instituída no âmbito da Sociedade das Nações, organismo internacional que antecedeu à Organização das Nações Unidas - ONU. Merece menção a Carta de Paris, de 1962, relativa à salvaguarda da beleza e do caráter das paisagens e sítios e também se destaca a importância do Parque Nacional de Yellowstone. Criado em 1872, nos Estados Unidos, foi o primeiro parque a ser preservado nos moldes atuais, sem a presença humana (Bensusan 2006). Para Choay (2001) a Itália foi a primeira nação a se preocupar com a conservação in situ dos seus monumentos, ainda no século XIX.

No caso do patrimônio construído, antigamente os reparos eram feitos substituindo-se toda a rocha degradada por um material novo similar, o que destruía a originalidade do monumento. Há, desta forma, que se fazer uma discussão sobre os aspectos éticos e estéticos da restauração (Fernandes 2008).

Serão apresentadas a seguir algumas tentativas isoladas de proteção contra as ameaças naturais e antrópicas, como a instalação de coberturas e até mesmo o soterramento dos geossítios, que podem deteriorar o valor científico, didático e estético destas localidades, quando não é realizado um planejamento adequado e análise crítica prévia.

Este trabalho tem ainda como objetivo enfatizar a necessidade do desenvolvimento e adaptação de metodologias específicas para a conservação e o restauro do patrimônio geológico. Assim sendo, são sugeridas linhas de ação para o controle da erosão, restauro de geossítios danificados e projetos de educação patrimonial, incluindo a participação de profissionais de diversas áreas para consolidar novos métodos de preservação do patrimônio geológico brasileiro.

Portanto, a fim de contribuir com a conservação in situ dos geossítios e com a conservação ex situ das amostras retiradas destas localidades (depositadas em coleções científicas) e de seus registros associados, optou-se por utilizar a separação proposta por Ponciano et al. (2011) de elementos in situ e ex situ do patrimônio geológico, a fim de aprofundar a discussão sobre as metodologias mais adequadas para a conservação e restauração dos elementos considerados como patrimônio em seu lugar de origem ou fora dele.

O componente in situ do patrimônio geológico é claramente identificado pela maioria dos geocientistas, estando ainda em processo de reconhecimento pela sociedade em geral. De outro modo, a caracterização do componente ex situ é complexa até mesmo entre a comunidade científica, ainda estando em debate quais elementos podem ser incluídos e, mesmo, se os elementos ex situ podem ser classificados como patrimônio geológico.

Segundo Ponciano et al. (2011), acompanhando o conceito de Brilha (2005), patrimônio geológico in situ corresponde ao conjunto de depósitos minerais ou fossilíferos (aflorantes ou não), paisagens e solos de uma determinada região, bem delimitados geograficamente, onde ocorrem elementos da geodiversidade com singular valor do ponto de vista científico, didático, cultural, estético, entre outros.

Os mesmos autores definem patrimônio geológico ex situ como os exemplares da geodiversidade retirados do seu sítio de origem para integrarem coleções científicas de instituições de pesquisa e os registros relacionados à coleta, guarda e estudo deste material e de outros elementos da geodiversidade que apresentem conspícuo valor científico, didático, cultural, estético, histórico entre outros. Citam como exemplos: (1) as coleções científicas de rochas, minerais, fósseis e solos em museus, universidades e outros institutos de pesquisa; (2) as publicações científicas raras ou históricas (livros e artigos em periódicos); (3) os dados científicos não publicados e com valor associado a aspectos da história da ciência ou sobre descobertas científicas (monografias, dissertações, teses, cadernetas de campo, fotografias, filmes, ilustrações, mapas, perfis estratigráficos, entre outros); (4) as reproduções (réplicas, esculturas, desenhos e pinturas) de fósseis, rochas e minerais e as reconstituições anatômicas, biomecânicas, paleoambientais, paleoecológicas e paleogeográficas realizadas com técnicas, métodos e conhecimentos vigentes em época pretérita; e (5) os instrumentos científicos e laboratórios antigos utilizados no desenvolvimento de estudos geológicos, paleontológicos e em áreas relacionadas.

\section{MARCO CONCEITUAL}

A deterioração das rochas pode ocorrer lentamente para a escala humana, entretanto alguns tipos são alterados com maior facilidade devido às suas características intrínsecas e à ação antrópica. Vandalismos e outros fatores, como a poluição atmosférica e hídrica, aceleram o processo intempérico (Reys et al. 2008).

A degradação natural das rochas pode ocorrer por processos químicos e físicos, que podem ser acelerados por agentes biológicos, devido (1) às reações que se processam na superfície e nas descontinuidades das rochas, com a formação de minerais secundários; (2) aos fenômenos de expansão e contração dos minerais, provocados por variações térmicas, abalos físicos de várias origens, e por expansões decorrentes da geração de minerais secundários (hidratação de minerais argilosos expansivos, ação da tensão superficial da água no decurso de processos naturais de saturação e secagem, e ação das forças de cristalização de sais); e (3) 
ao crescimento de micro-organismos e vegetais sobre as rochas, além dos detritos fecais de diversos tipos de animais, como pássaros, morcegos e roedores (AiresBarros 1991). Em cavernas, por exemplo, a simples presença de visitantes pode aumentar a umidade relativa do ambiente, o que pode danificar espeleotemas e outros elementos do geossítio. Isto, quando não são depredadas por visitantes, como vem ocorrendo desde com as cavernas mais conhecidas do país, como a Gruta de Maquiné, até outras de menores dimensões (Figuras 1 e 2).

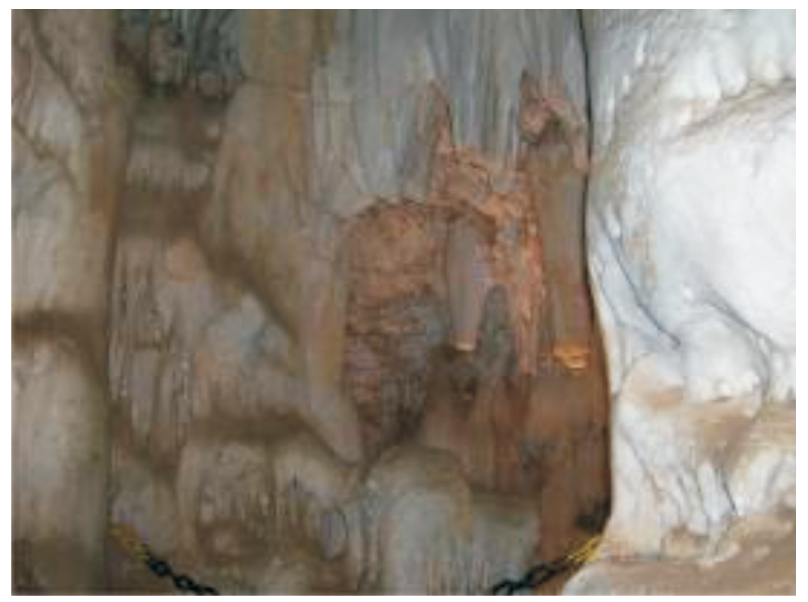

Figura 1 - Espeleotemas danificados por depredação. Gruta de Maquiné, MG, uma das mais importantes e famosas do Brasil (Fotografia: Kátia Mansur, 2007).

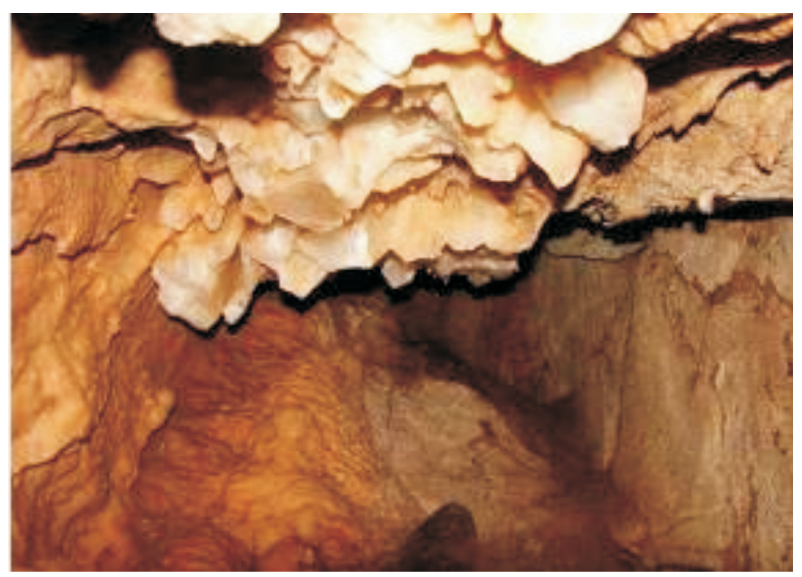

Figura 2 - Espeleotemas danificados por depredação. Caverna da Pedra Santa, em Cantagalo - RJ, uma das poucas cavernas calcárias mapeadas no estado foi fechada para a visitação porque seus espeleotemas vêm sendo destruídos (Fotografia: IBAMA Nova Friburgo).

Por outro lado, deve-se destacar que intervenções efetuadas com o objetivo de conservação e restauro do patrimônio não devem ultrapassar o limiar da preservação do seu valor intrínseco. Por esta razão, antes da intervenção, é necessário definir uma metodologia adequada às características de cada geossítio: documentar e registrar todas as ações realizadas durante a restauração, a metodologia, os materiais e as análises empregadas (modificado de Reys et al. 2008). Um bom exemplo a ser citado é o estudo para restauração de rochas no sítio arqueológico do Vale do Côa, em Portugal, onde ensaios e experiências foram realizados por empresas que utilizaram técnicas e abordagens diversas, com o intuito de preservar pinturas rupestres em xisto, ameaçadas por intemperismo e erosão (Fernandes 2008). No Brasil, sítios arqueológicos de alta relevância, sofrem com deterioração natural e depredação antrópica (Figura 3 a 6).

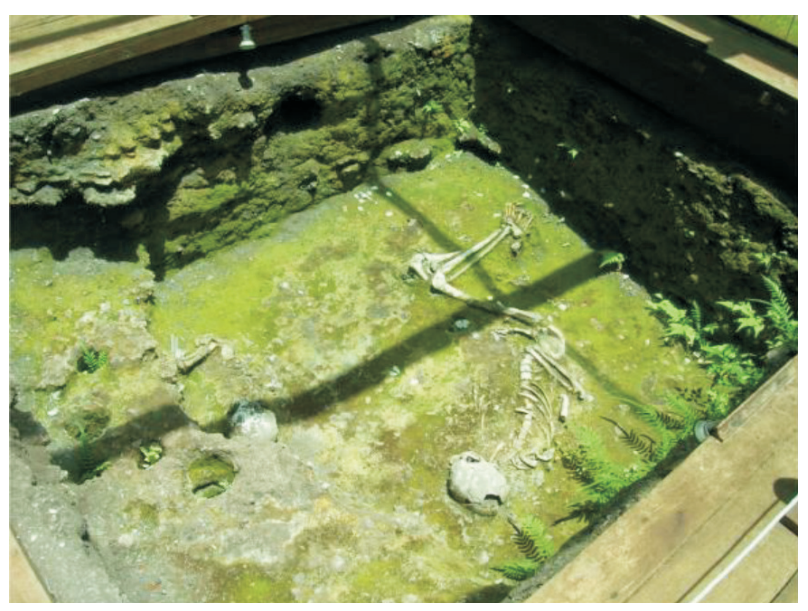

Figura 3 - Deterioração natural em sítios arqueológicos. Crescimento de líquen e vegetação sobre parte da exposição in situ do Sambaqui da Tarioba, em Rio das Ostras, RJ. Em 2012 este sítio foi fechado temporariamente à visitação para que fosse feita manutenção e higienização do afloramento (Fotografia: Kátia Mansur, 2010).

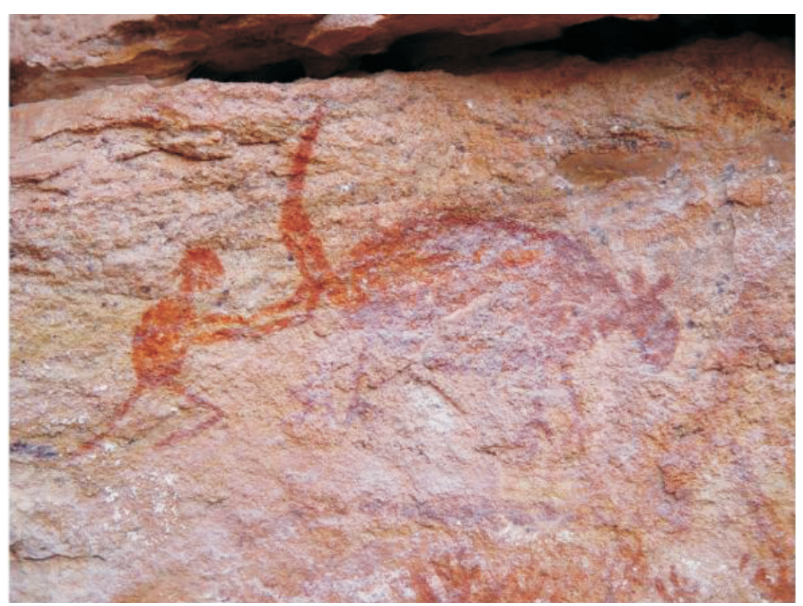

Figura 4 - Deterioração natural em sítios arqueológicos. Eflorescência salina em painel de pinturas da Serra da Capivara, Piauí (Fotografia: Ismar de Souza Carvalho, 2010). 


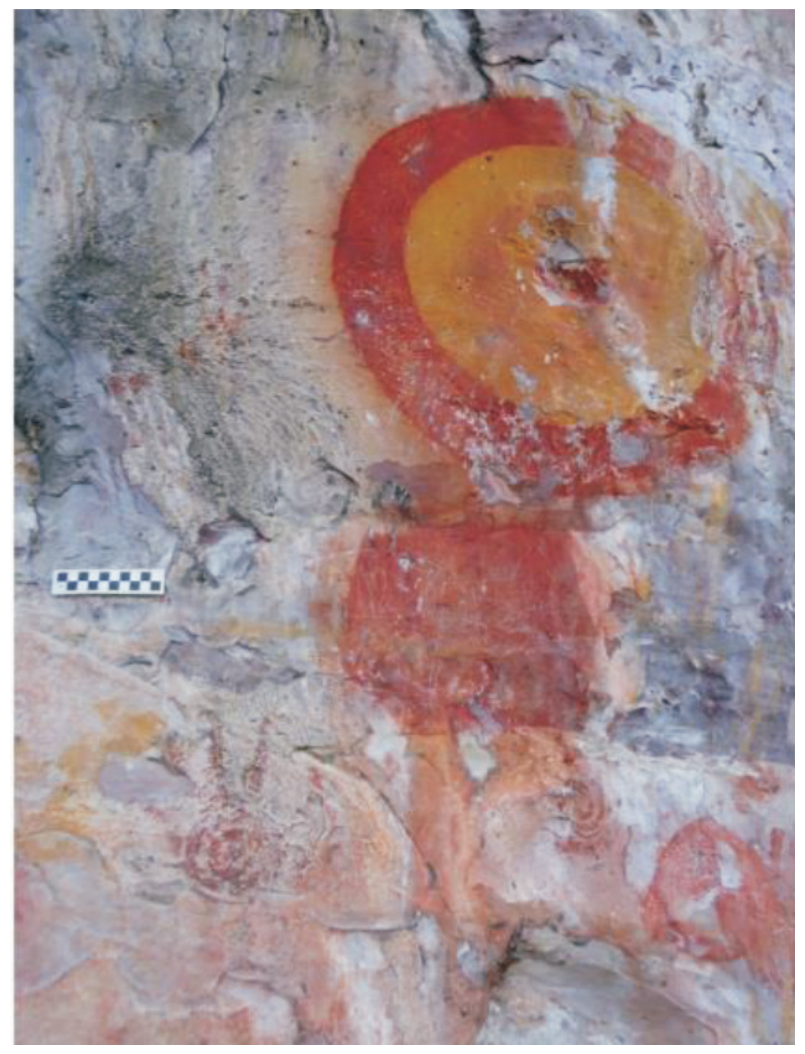

Figura 5 - Depredação em sítios arqueológicos. Pintura rupestre usada como alvo de tiros na Serra da Lua, Pará (Fotografia: Marcela Nogueira de Andrade).

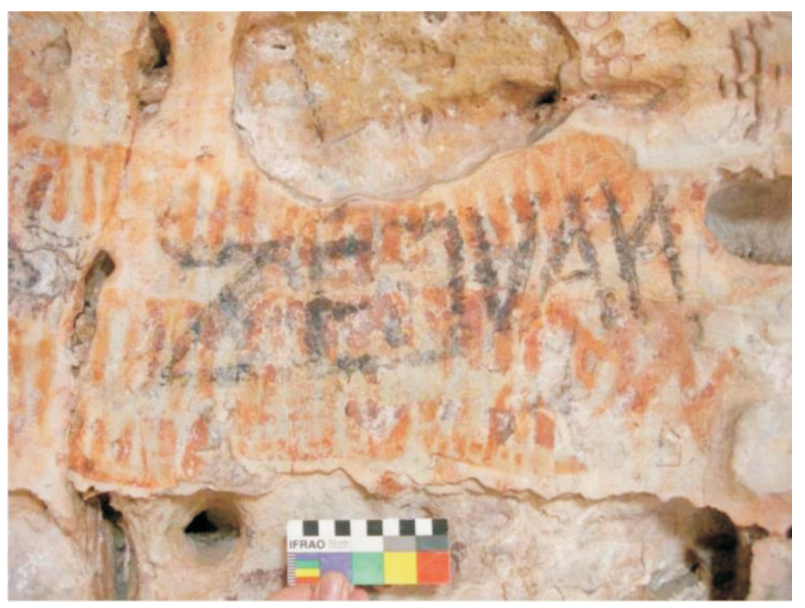

Figura 6 - Depredação em sítios arqueológicos. Pichação sobre pintura rupestre na Pedra do Castelo, Piauí (Fotografia:hyperlinK"http://www.restaurabr.org/siterestaura br/ARC_Vol_3/CONSERVACAODEARTERUPESTRENONORDEST EDOBRASILluiscavalcante.pdf"http://www.restaurabr.org/site restaurabr/ARC_Vol_3/CONSERVACAO\%20DE\%20ARTE\%20R UPESTRE\%20NO\%20NORDESTE\%20DO\%20BRASIL\%)uis\%)20c avalcante.pdf).
Os métodos hoje utilizados para restauro são cada vez mais eficientes e consideram o aspecto final do bem restaurado de formas variadas, de acordo com a abordagem teórica escolhida. Desde o século XIX, duas correntes se destacaram como tendências antagônicas no ocidente, lideradas por Viollet-le-Duc, na França, e John Ruskin, na Inglaterra. A tendência francesa é mais intervencionista e defende o retorno, o mais próximo possível, à aparência original do bem. Já a inglesa defende a postura de que as intervenções sejam realizadas apenas para a consolidação do monumento, descartando as questões estéticas (Braga 2003).

A evolução desses conceitos resulta na teoria do restauro crítico criada por Cesari Brandi na década de 1930, na Itália. Brandi estabelece critérios para intervenções de restauro, onde são considerados tanto valores estéticos quanto históricos. Reintegrações são permitidas desde que preservando a autenticidade da obra. O tratamento das lacunas deve ser reconhecível quando visto de perto, buscando a unidade potencial da obra. Dois princípios básicos foram estabelecidos: o de utilização de materiais reversíveis e o da mínima intervenção. Quando não é possível o uso de materiais reversíveis, deve-se procurar por aqueles que aceitem novos tratamentos, o que foi denominado como terceiro princípio, o da compatibilidade (Brandi 2000).

A princípio, pode-se analisar o conceito de patrimônio por sua origem etimológica, como sendo algo de valor que é passado ou herdado por uma nova geração (Gonçalves 2002; Assunção 2003). Na atualidade, segundo Grunberg (2000), o significado permanece, e pode ser também atribuído a um bem cultural, ou seja, àquilo através do qual se pode compreender e identificar uma determinada cultura, situado em um determinado local e tempo. Um bem cultural ou um patrimônio constituem uma evidência concreta de experiência do passado. Se isso não ocorrer, não há sentido na sua preservação (Grunberg 2000).

O próprio conceito de Patrimônio remete à ideia de valor, o que nos permite lembrar o seu caráter de signo. É uma poderosa construção sígnica, constituída e instituída a partir de percepções identitárias e integralmente vinculada ao sentimento de pertença, a partir do qual se reflete em todos os jogos da memória e se expressa em todas as representações sociais. Em outras palavras, expressa as relações que cada grupo social estabelece com a natureza ou com sua produção cultural, estando diretamente influenciado pelas maneiras sob as quais cada sociedade compreende Natureza e Cultura (Scheiner 2006).

Um patrimônio pode ser dividido em bens tangíveis e intangíveis. O primeiro reúne qualquer evidência material, como construções e documentos. 0 segundo corresponde aos elementos que não se materializam, ocorrem em um determinado tempo, mas não se perpetuam, como o modo de fazer, as danças, as receitas culinárias, entre outros. Estes se preservam 
através da tradição e da sua prática (Grunberg 2000). No que tange ao patrimônio geológico, pode-se encontrar estas duas formas. As técnicas de coleta, preparação, métodos de lavra e outros modos de fazer são partes do patrimônio intangível, enquanto que os afloramentos, paisagens e amostras, por exemplo, são tangíveis.

Para Fonseca (2005), o patrimônio situa-se entre dois pontos, o primeiro correspondente às identidades coletivas, envolvendo questões como memória e tradição, e o segundo envolvendo a sua utilização como meio de legitimar a ideia de nação. Em ambos os casos, o que muda é o valor simbólico atribuído ao bem cultural. Ressalta-se que há o entendimento que os bens naturais podem ser compreendidos como culturais, uma vez que estão diretamente associados às apropriações e atribuições de valor, produtos da ação humana. Um objeto, uma paisagem, uma área, um documento, ou até uma dança ou procissão, enquanto estão apenas com a sua atribuição de funcionalidade, não são patrimônio. A diferença está na interpretação que autoridades legítimas realizam ao atribuir um valor simbólico de excepcionalidade perante os demais (Lima 1997). A reinterpretação que se faz do produto cultural ao qualificá-lo na categoria de bem cultural é uma atribuição de valor, um juízo elaborado pelo campo cultural que o consigna como elemento possuidor de caráter diferencial, que o distingue, tornando-o especial e em posição de destaque perante os demais objetos da natureza (Lima 1999).

De modo diverso do patrimônio construído, as metodologias de conservação e restauração do patrimônio geológico são tratadas de modo disperso e superficial na literatura. A maioria dos trabalhos existentes aborda outras etapas das medidas necessárias para a promoção da geoconservação, conforme indicado por Brilha (2005).

\section{CONSERVAÇÃo DE SítIOS GEOLÓGICOS E PALEONTOLÓGICOS INSITU}

A geoconservação, ou conservação do patrimônio geológico, pressupõe a adoção de medidas como inventário, quantificação, proteção legal, divulgação, conservação e monitoramento de geossítios (Brilha 2005). Existem diversas publicações tratando de algumas destas medidas. No entanto, pouco material encontra-se disponível sobre a conservação in situ do patrimônio geológico na forma de geossítios ameaçados pela ação antrópica ou natural.

A conservação de ao menos uma parte do patrimônio geológico in situ poderia ser viabilizada adaptando-se a metodologia da Arqueologia de manutenção de blocos testemunhos (Delphim 2004), assegurando assim que ao menos uma parte dos sítios seja preservada para pesquisas futuras. Além da questão científica, a conservação do patrimônio geológico in situ também é relevante pela manutenção da potencialidade de desenvolvimento sustentável no local na forma de projetos de geoturismo e educação patrimonial. Contudo, a continuidade das pesquisas científicas pode ser afetada dependendo do tipo de estratégia de conservação aplicada ao patrimônio in situ. Se o tombamento for escolhido para um determinado geossítio, as pesquisas que dependem de coleta de material poderiam de ser interrompidas, por exemplo, se isto não estiver previsto no ato normativo do tombamento. Caso o sítio possua elementos muito frágeis e mesmo assim seja divulgado para receber turistas antes da instalação de estruturas de proteção, o patrimônio pode acabar sendo rapidamente depredado (Ponciano et al. 2011; Souza et al. 2007). Para que a conservação do patrimônio in situ seja efetiva é necessária uma estrutura de fiscalização eficiente e a integração com outras políticas de conservação, a fim de evitar vandalismos ou furtos nos geossítios. Estes atos geralmente estão relacionados com a ação de "paleo-piratas" ou "geovândalos", grupos que além de furtarem fósseis também destroem afloramentos e seu entorno (Fedonkin et al. 2009). Porém, alguns geocientistas (formados ou em formação) também são responsáveis por diversos tipos de depredação, seja por ignorância ou omissão. Marcações de símbolos e números feitas em tinta permanente, por exemplo, não deixam de ser pichações só porque foram feitas por pesquisadores. Afloramentos históricos e muito utilizados para fins científicos, didáticos e turísticos deveriam ter ao menos suas partes principais conservadas do melhor modo possível.

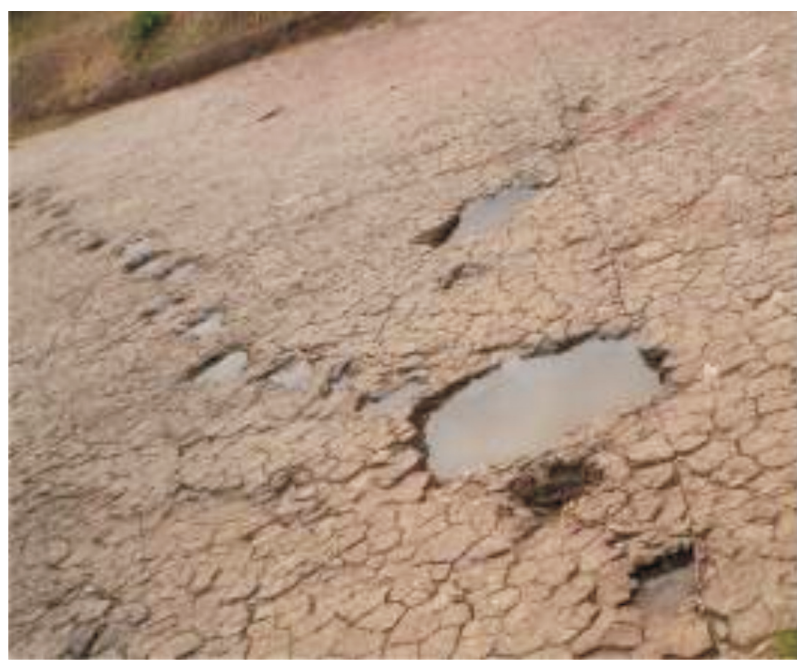

Figura 7 - Amostra coletada na pista de pegadas de dinossauros em Sousa, Paraíba, danificou a integridade do geossítio. 


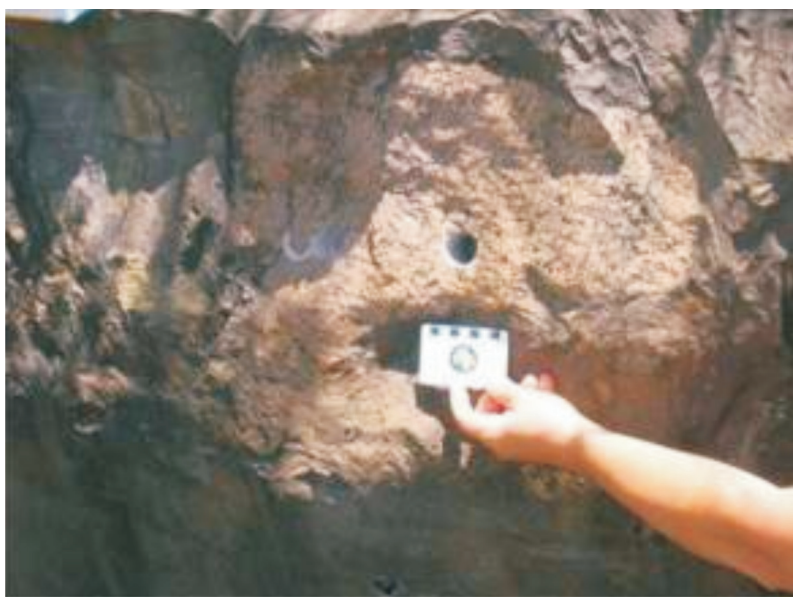

Figura 8 - Afloramento de diamictito da Formação Bebedouro, na Chapada Diamantina, onde a extração de amostras do clasto de gnaisse causou danos ao afloramento (Fonte: Mansur, 2009).

Devido à maior exposição ao intemperismo, o patrimônio geológico in situ deve ser constantemente monitorado, pois, mesmo em locais com baixo impacto antrópico, os processos naturais também causam a destruição de exemplares da geodiversidade ou inviabilizam o acesso aos afloramentos. Um exemplo de conservação in situ integrada com o componente ex situ é o do Museu "Phu Kum Khao Dinosaur Site", na Tailândia (Boonchai et al. 2009) e Geoparque Lesvos, na Grécia. No Brasil, alguns exemplos de conservação in situ combinada com musealização de sítios arqueológicos também são conhecidos, como sambaquis no Rio de Janeiro e petroglifos em Santa Catarina (Figuras 9 a 14). Assim, com o objetivo de reduzir os efeitos da exposição contínua às alterações naturais, diversos tipos de estruturas de proteção são construídos, como coberturas para sombreamento ou isolamento do material, andaimes para controlar e facilitar o acesso dos visitantes e barreiras para escoramento ou desvio de águas superficiais. Contudo, estas interferências podem ser exageradas ou equivocadas, ocasionando até mesmo o desinteresse dos visitantes pelos geossítios. A instalação de estruturas deve ser bem planejada, de preferência por uma equipe multidisciplinar, com base em uma ampla análise das características dos geossítios e do clima local, para orientar a escolha dos melhores tipos de materiais e metodologias. A implantação de barreiras físicas, como coberturas, muros, grades e cercas, também pode ser empregada para impedir a aproximação dos visitantes de elementos mais vulneráveis, porém não pode obstruir a visualização dos objetos de interesse (Mansur \& Nascimento 2007; Ponciano et al. 2011).

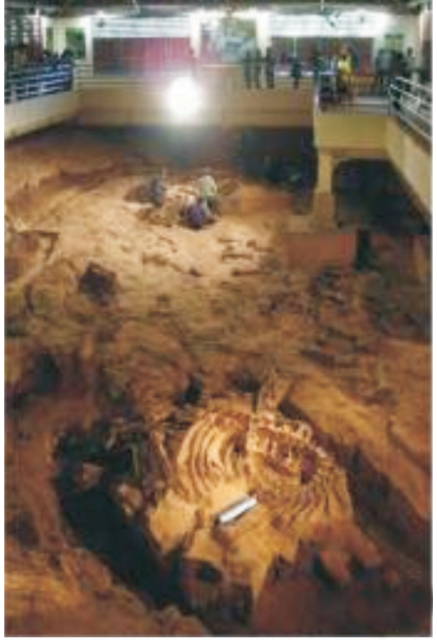

Figura 9 - Exemplo da união dos dois modos de conservação. Museu "Phu Kum Khao Dinosaur Site" construído ao redor de um geossítios com os fósseis in situ, na Tailândia (extraída de Boonchai et al. 2009). O clima úmido local é um sério problema para a conservação do afloramento e, em 1999, um prédio permanente foi construído cobrindo o afloramento.

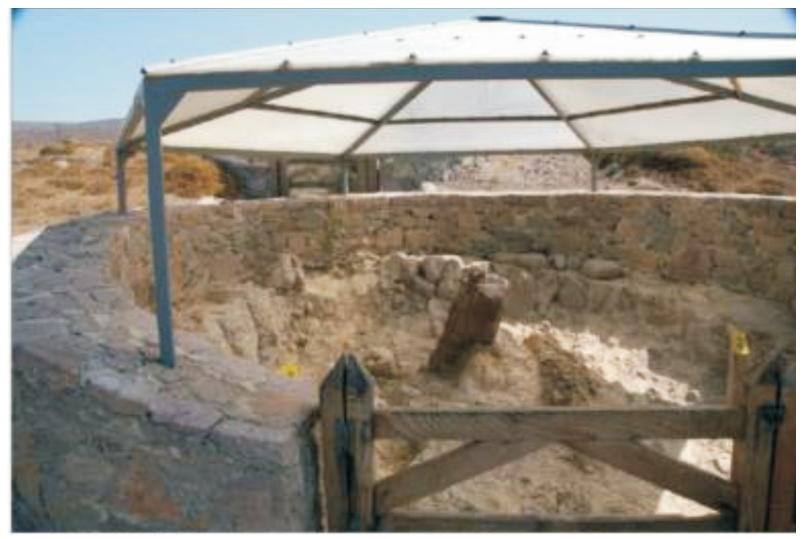

Figura 10-Afloramento do Geoparque de Lesvos (Grécia), onde uma estrutura foi construída para proteger in situ os troncos fossilizados. O resultado estético desta intervenção é inadequado (fotografia extraída de apresentação de José Brilha).

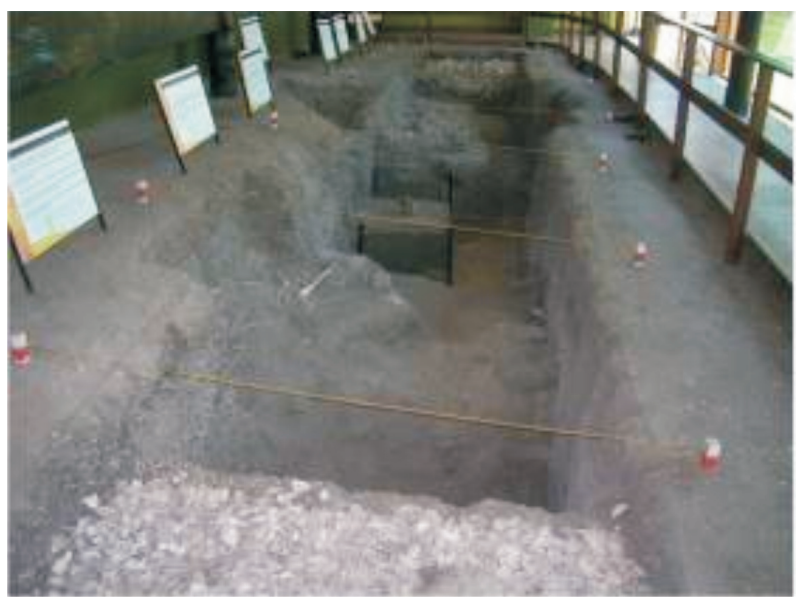

Figura 11 - Musealização in situ no Sambaqui da Tarioba, em Rio das Ostras, RJ (Fotografia: Kátia Mansur, 2010). 


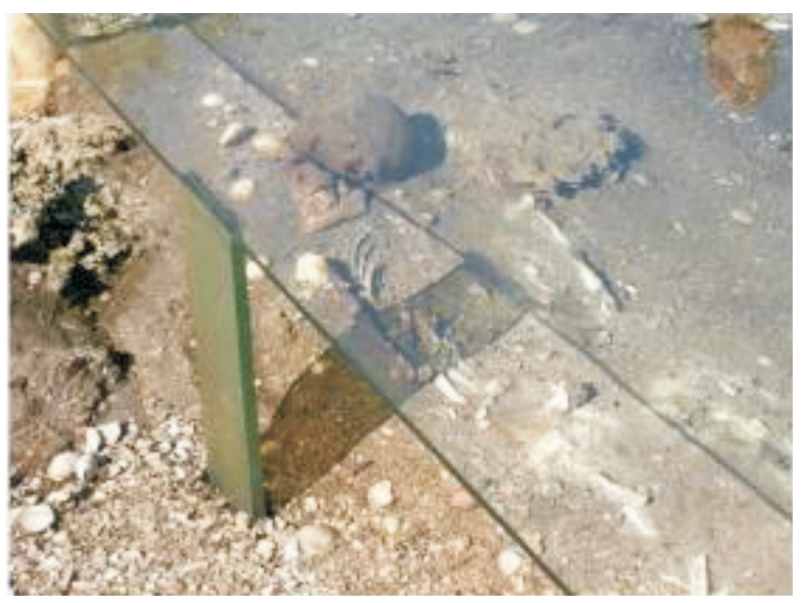

Figura 12 - Musealização in situ no Sambaqui da Beirada, em Saquarema, RJ (Fotografia: Felipe Medeiros, 2006).

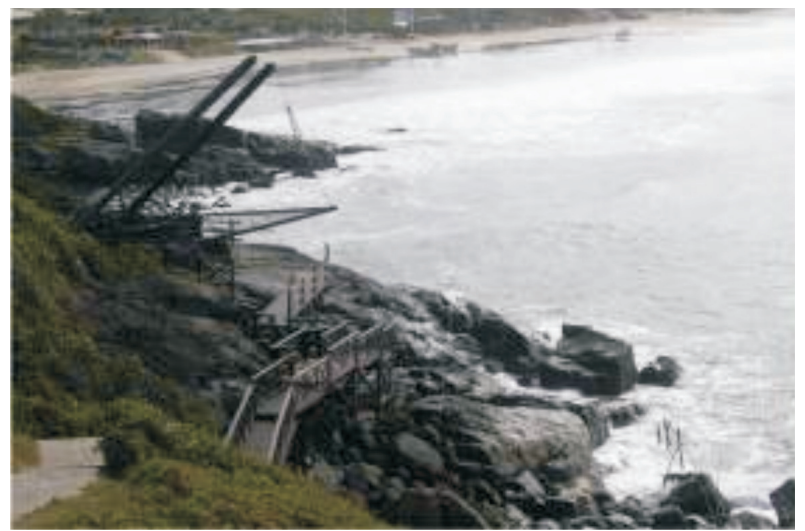

Figura 13 - Estrutura construída para proteção dos petroglifos no Costão do Santinho, Florianópolis, SC. Fotografia: http://trilhasemfronteiras.blogspot.com.br/2009/06/sitioarqueologico-no-costao-do.html.

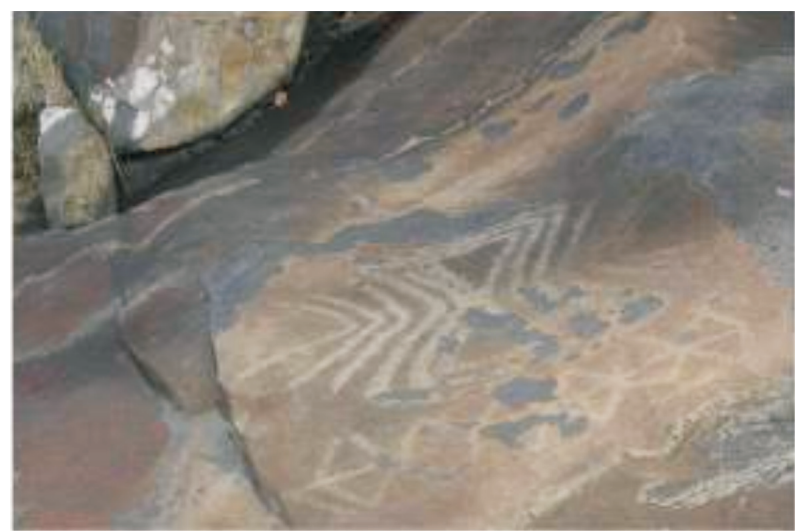

Figura 14 - Costão do Santinho, Florianópolis: petroglifo sofrendo intemperismo que produz esfoliação na rocha ( I COMOS, 2008 ). Fot og r a f a : http://trilhasemfronteiras.blogspot.com.br/2009/06/sitioarqueologico-no-costao-do.html.
Talvez por falta de tradição na área de conservação e restauro de sítios geológicos in situ, observa-se que, na tentativa de conservar um geossítio, às vezes são utilizados métodos que podem colocá-lo em maior risco ou comprometer seu caráter estético. A Figuras 15 a 19 ilustram alguns sítios geológicos, paleontológicos e arqueológicos ameaçados por ação natural ou antrópica que sofreram intervenções com objetivo de conservação e restauração. Um caso exemplar para a discussão de conservação in situ no Brasil é o dos pavimentos com pegadas de dinossauro em Sousa, na Paraíba, conhecido como o Vale dos Dinossauros. A erosão fluvial, o intemperismo e as inundações vêm colocando em risco este que é um dos sítios paleontológicos e arqueológicos (representados pelos petroglifos associados aos icnofósseis) mais importantes do Brasil.

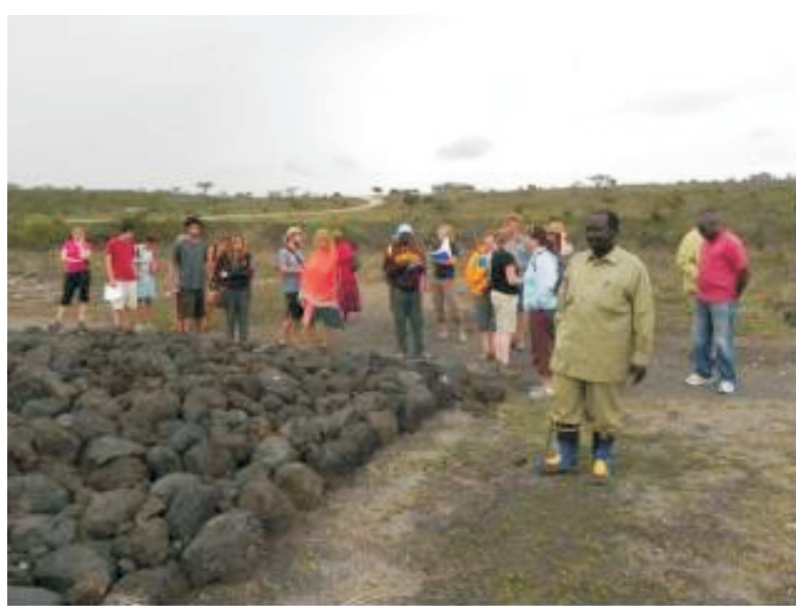

Figura 15 - Sítio de Laetoli, na Tanzânia: são as mais antigas pegadas de humanoides (3,7 milhões de anos), impressas sobre cinza vulcânica. O geossítio foi recoberto por solo para impedir a erosão e destruição antrópica. Posteriormente, sementes presentes no solo utilizado neste processo brotaram e colocaram a área em risco de destruição ainda maior. Discutese, inclusive, a retirada das placas com as pegadas para sua realocação em um museu (Fotografia: http://www.africanarchaeology.net/news/news.html). Vista do sítio recoberto por rochas em 2011. Importante ressaltar a ineficiência do uso turístico, didático ou científico do sítio enquanto permanecer esta condição, mas a sua integridade deve vir em primeiro lugar. 


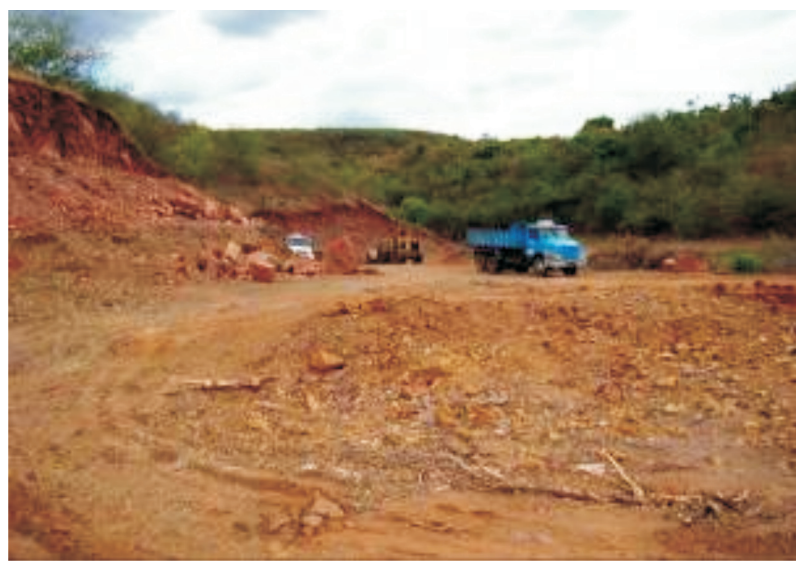

Figura 20 - Destruição de afloramento fossilífero da Formação Pimenteira, na entrada da cidade de Picos (PI). Toda a área plana da fotografia era a continuação do morro visto ao fundo. Este afloramento, rico em icnofósseis e concreções fossilíferas, foi removido entre 2009 e 2011 para aterrar o buritizal da figura 21, visando a construção de um estacionamento (Fotografias: Luiza Ponciano, 2012).

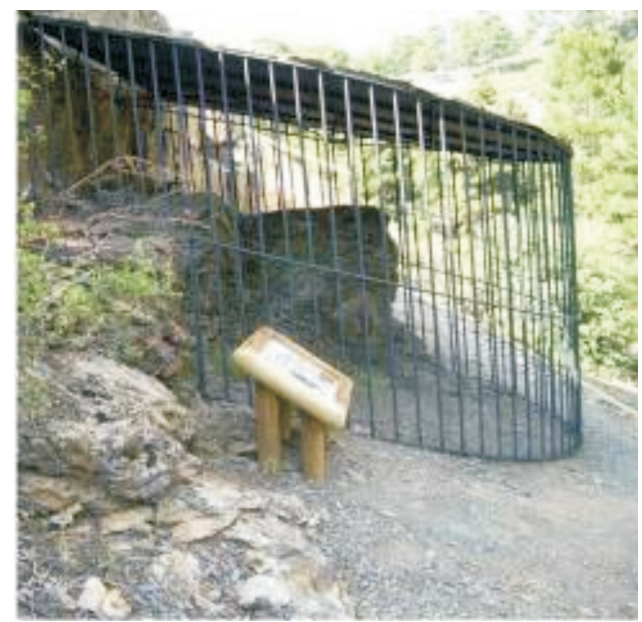

Figura 16 - Espanha: afloramento de depósito glacial com dropstones, no Parque Alto Tajo, protegido com grades para evitar geovandalismo. Infelizmente as grades também causam um efeito secundário negativo junto aos visitantes (Fotografia: Luis Carcavilla).

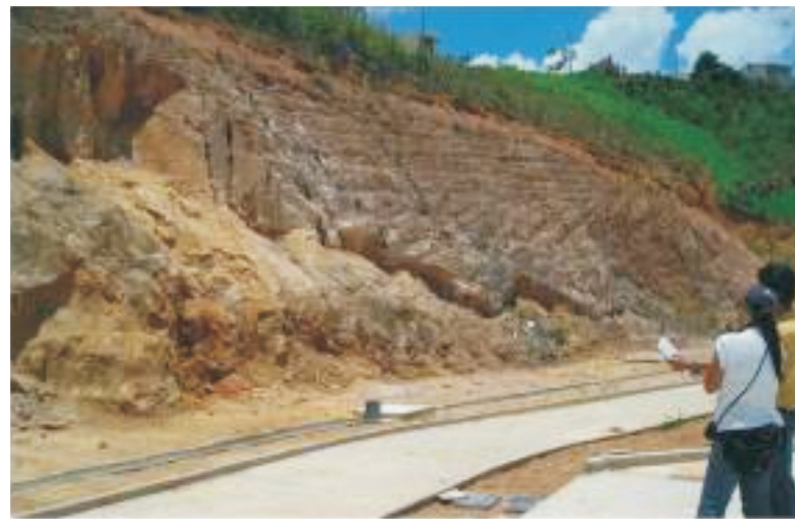

Figura 17 - Volta Redonda, RJ: construção de praça na tentativa de conter a erosão em afloramento de depósitos sedimentares com evidências de neotectônica, onde se conseguiu evitar o revestimento do afloramento por grama após explicar a importância didática do local para os moradores (Fotografia: Luiza Ponciano, 2007).

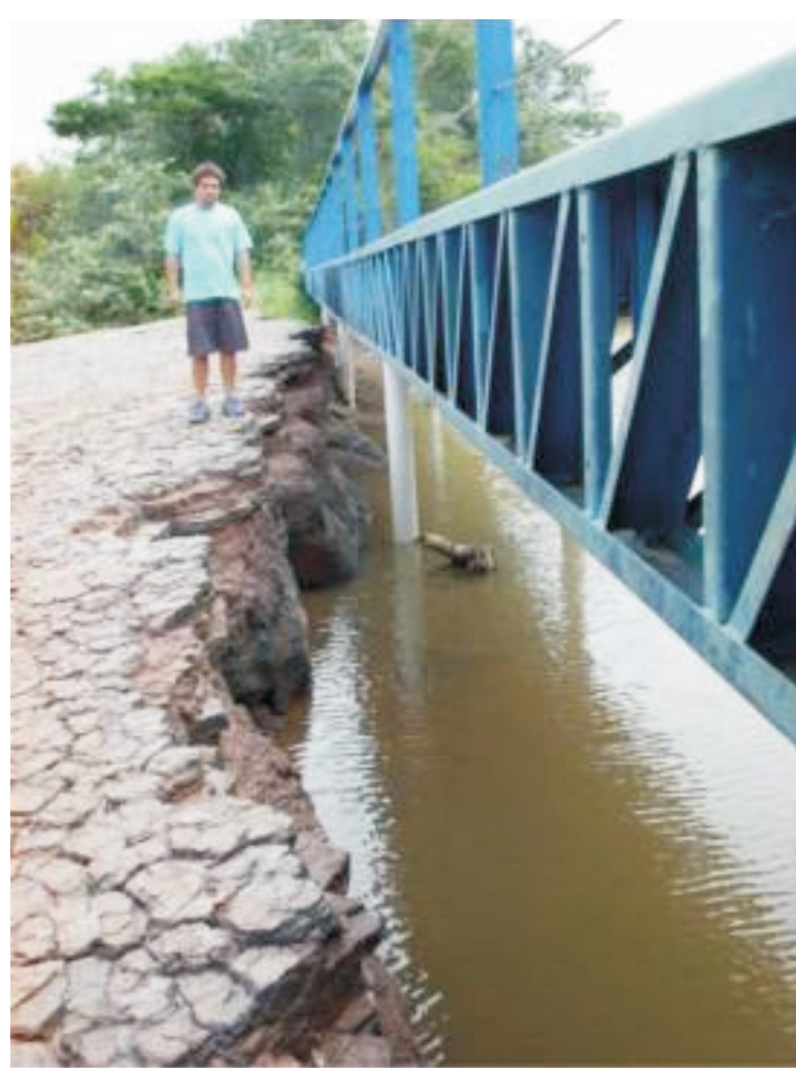

Figura 18 - Sousa, PB: erosão fluvial no pavimento que contém as pegadas de dinossauros (Fotografia: Ismar Carvalho, 2010).

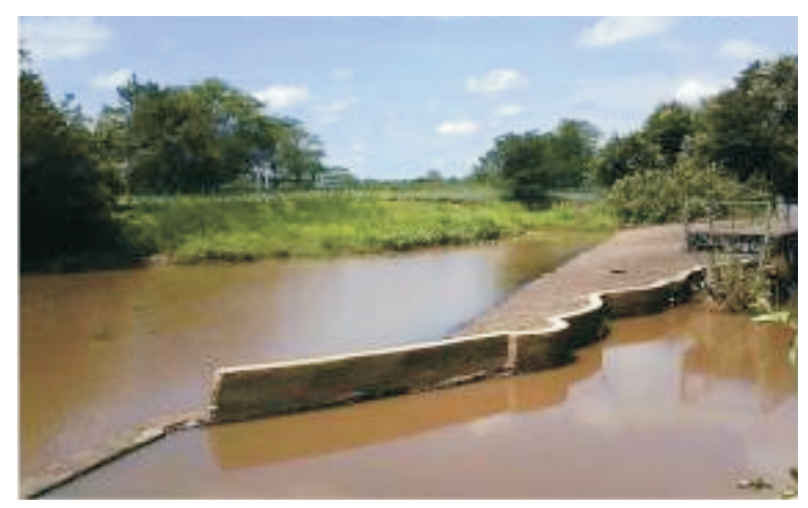

Figura 19 - Rio Piranhas, Parque Vale dos Dinossauros, Sousa, Paraíba - Foi construído um muro que, infelizmente, não consegue deter as águas durante o período chuvoso (Fotografia: Aline Castro, 2012).

Por vezes é o crescimento das cidades que provoca a destruição de geossítios. Este é o caso da cidade de Picos (Piauí), onde os afloramentos fossilíferos são sistematicamente removidos para serem utilizados em aterros de rios e áreas alagáveis (como os buritizais) visando à construção de casas no centro da cidade. Os afloramentos que ainda resistem e são acessíveis não recebem qualquer tipo de proteção ou indicação de existência. Algumas localidades fossilíferas citadas na literatura já não podem mais ser encontradas, pois os pontos de referência utilizados desapareceram (Souza 2006; Ponciano et al. 2010, 2012). 


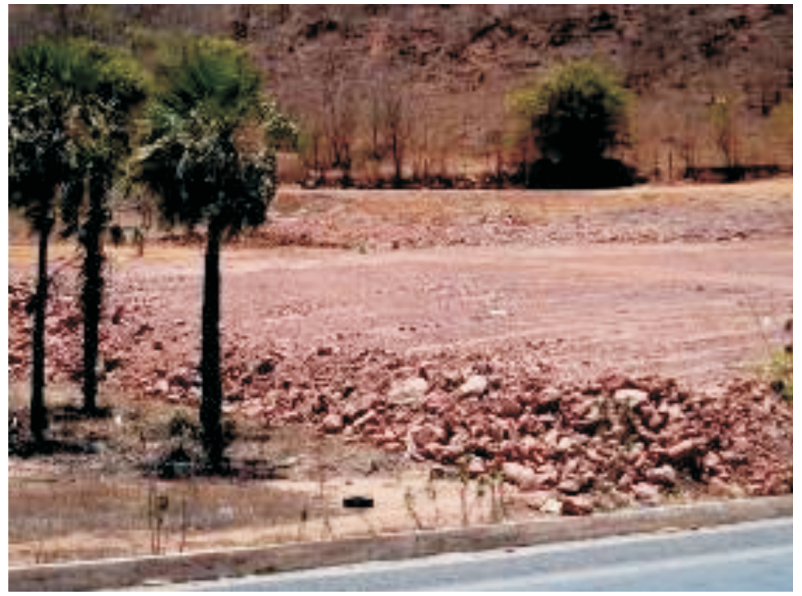

Figura 21 - Buritizal em Picos (PI), citado na figura 20 (Fotografia: Luiza Ponciano, 2012).

Tais problemas são agravados pelo desconhecimento da importância destes geossítios pela população do entorno, que ainda necessita ser apresentada e conscientizada sobre o significado dos fósseis que podem ser encontrados nos quintais de suas casas em Picos. A retirada dos fósseis sem a preocupação com a educação e conscientização da comunidade gera ameaças ao patrimônio geológico, pois quando os pesquisadores saem dos sítios os moradores podem acabar depredando o local na busca por materiais de valor econômico. Cita-se o exemplo dos clastos facetados incrustados em pavimentos estriados no sul do Piauí (Caputo \& Ponciano 2010) que foram parcialmente arrancados pela população local após verem pesquisadores fotografando e tomando medidas na localidade. A falta de comunicação com os moradores pode chegar a originar conflitos, e a comunidade pode tentar impedir o acesso dos pesquisadores aos afloramentos.

Situação similar ocorre com os afloramentos do Membro Crato, da Formação Santana da Bacia do Araripe, entre os municípios de Santana do Cariri e Nova Olinda, Ceará. A maior parte dos geossítios são pedreiras em atividade, onde a extração do calcário laminado não é legalizada (Figuras 22 e 23). Estas pedreiras representam uma das poucas oportunidades de emprego nesta região, porém provocam impactos ambientais relevantes como remoção da cobertura de solo, retirada da mata úmida, destruição dos corpos hídricos e disposição inadequada de rejeitos. Os fósseis encontrados nestes afloramentos possuem inegável valor científico, tanto pela diversidade de organismos, quanto pela qualidade da preservação que apresentam. Nesta conjuntura, a grande dificuldade que envolve a conservação do geossítios da região é conseguir conciliar os interesses econômicos, científicos e sociais. As iniciativas de educação não formal podem ser uma boa opção. Nas Figuras 24 e 25 podemos verificar um projeto de divulgação e educação realizado pelo Geoparque
Araripe, através da criação do Geossítio Pedra Cariri, num trecho de uma pedreira abandonada. Neste geossítio é possível obter informações sobre a geologia e os fósseis encontrados ali, assim como o seu processo de extração. No entanto, este exemplo também demonstra que ainda é necessária uma maior discussão sobre a musealização de geossítios, principalmente quando os fósseis não estão expostos.

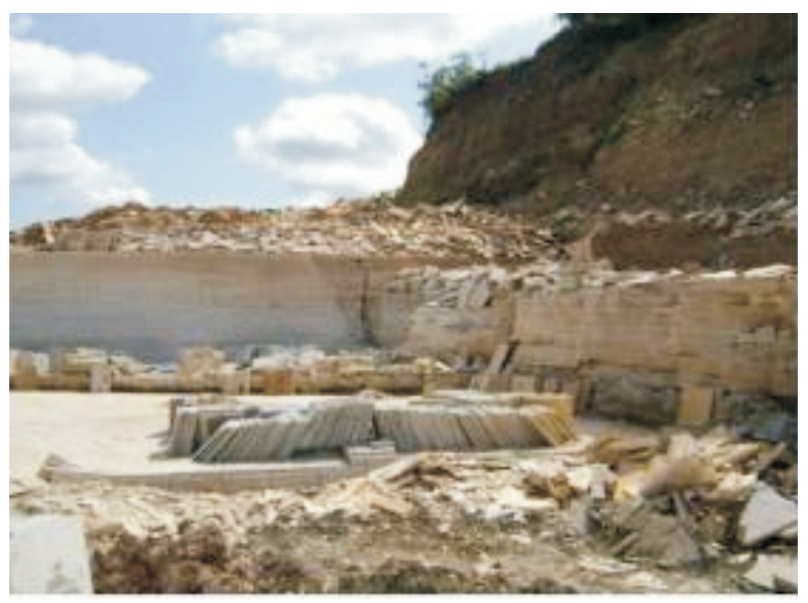

Figura 22 - Bacia do Araripe: Mina Pedra Branca, onde as lajes de calcário laminado (ou pedra cariri) são extraídas. Através desta atividade, fósseis são encontrados diariamente. (Fotografia: Aline Castro, 2012).

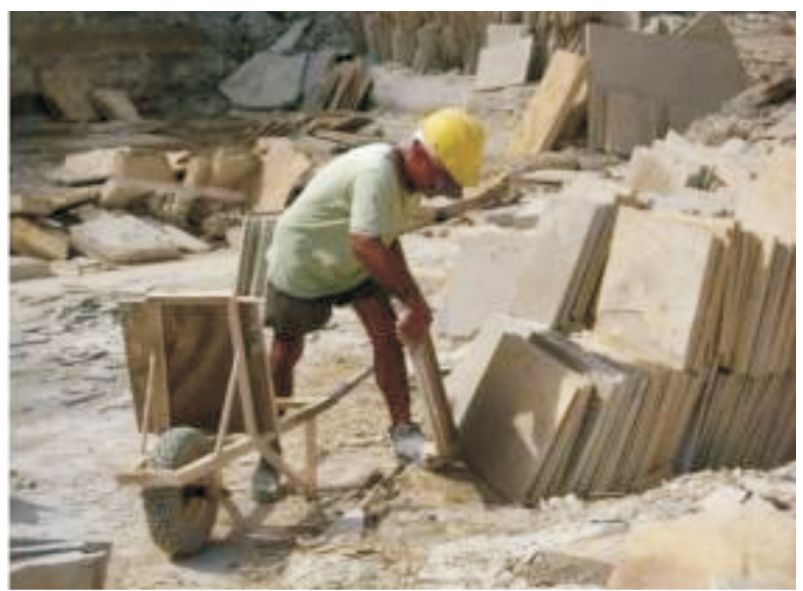

Figura 23 - Bacia do Araripe: trabalhador manejando as lajes. Esta atividade apresenta-se como alternativa de emprego e movimenta a economia da região (Fotografia: Aline Castro, 2012). 


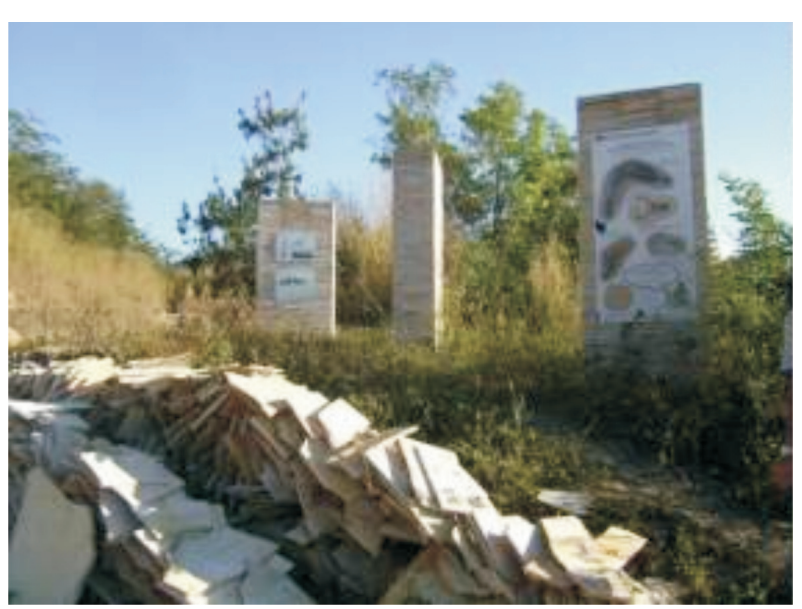

Figura 24 - Geoparque Araripe: geossítio Pedra Cariri, com destaque para os painéis interpretativos. (Fotografia: Aline

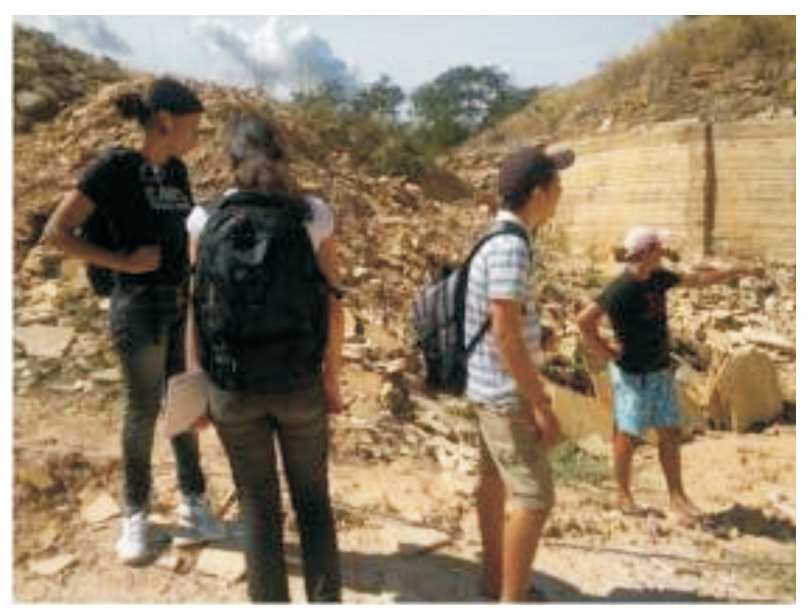

Figura 25 - Bacia do Araripe: alunos da rede pública que fazem parte do Programa Jovens Talentos, coordenado pelo Geopark Araripe. O programa consiste na conscientização dos trabalhadores das pedreiras e no recolhimento de fósseis doados para o Museu de Paleontologia de Santana do Cariri (Fotografia: Aline Castro, 2012).

\section{CONSERVAÇÃO DOS ELEMENTOS EX SITU DO PATRIMÔNIO GEOLÓGICO}

O patrimônio geológico ex situ, sob a forma de coleções científicas, é resultado da coleta dos fósseis em locais com risco de degradação, incorporando-os a um ambiente controlado. Idealmente, diversos fatores como a umidade, temperatura, sujidades e acesso de pessoal teriam de ser constantemente monitorados. Este ambiente representa uma área de segurança, onde o acervo é registrado, documentado, sofre intervenções (quando necessário) e é acondicionado em mobiliário adequado (Ponciano et al. 2011, Souza et al. 2007).

Além da guarda das cadernetas de campo, as informações mais relevantes sobre a coleta do material também devem ser registradas em fichas catalográficas, no período mais breve possível após o recebimento das amostras e de preferência com a participação dos próprios coletores. O controle terminológico de tais fichas deve ser padronizado, pois auxiliará na posterior recuperação da informação. Ao serem inseridos no acervo, os fósseis, rochas e outros elementos da geodiversidade devem ser acondicionados e documentados corretamente por profissionais experientes contratados especialmente para este fim, os curadores. Estes são responsáveis pela conservação, guarda, manutenção, seleção de acervo e dos sistemas de documentação da coleção. Os sistemas de documentação são tão importantes quanto os próprios acervos, pois neles está registrada a memória de cada exemplar. Por isso, o correto acondicionamento da documentação, bem como sua automação e disponibilização do banco de dados via Internet são medidas de segurança consideradas essenciais (Souza et al. 2007). Ainda referente à importância da documentação, destaca-se o trabalho do Comitê de Documentação do Conselho Internacional de Museus (ICOM), o CIDOC. O Comitê recomenda algumas diretrizes para museus ou instituições de pesquisa que queiram realizar um tratamento museológico sobre o seu acervo. As diretrizes são extensas e, por isso, serão destacadas apenas aquelas consideradas mais importantes pelas autoras. Todas as demais informações podem ser consultadas no sítio do CIDOC (http://icom.museum/the-committees/).

A documentação do acervo sempre deve ser a mais completa possível e a ficha catalográfica deve conter inúmeros campos, mesmo que nem sempre estes sejam preenchidos. Estas fichas devem conter informações que conectam a ficha ao objeto, ou seja, o registro de uma numeração que remeta ao local onde o acervo está depositado (gaveta ou armário) e ao próprio acervo (lastro).

Outras informações, além das classificações taxonômicas e litoestratigráficas usuais em acervos geopaleontológicos, devem integrar a ficha. Esses campos devem remeter (1) à forma de aquisição do acervo e nomes dos coletores; (2) à integridade do objeto (conservação), (3) ao número e se possível identificação dos espécimes da amostra; (4) às suas medidas e outras características, com descrição por escrito; (5) à instituição de guarda e informações dos curadores, entre muitos outros. Informações que registram a memória do acervo (como fotografias do objeto e do local de proveniência, mapas de localização e as cadernetas com as informações dos trabalhos de campo) também são muito importantes, sendo raras as instituições que efetuam tal registro. Também integram a memória do objeto os dados de empréstimo, participações em exposições, figuração em artigos, os números de tombo recebidos anteriormente (como os do livro de entrada ou de outras coleções), entre outras possibilidades.

O processo de musealização e patrimonialização adotado para os fósseis, rochas e 
minerais também pode ser utilizado, com algumas adaptações, para a guarda de suas reproduções e informações relacionadas. Aconselha-se inclusive a inserção de réplicas, esculturas, desenhos, pinturas e instrumentos antigos nas coleções dos museus, universidades e outros institutos de pesquisa brasileiros, desde que (re)significados como patrimônio.

A conservação das publicações científicas raras e/ou históricas e dos dados científicos não publicados possibilita a recuperação de valiosas informações sobre sítios que já foram destruídos pelo crescimento das cidades ou exploração comercial. A digitalização dos acervos pelas bibliotecas tem sido importante aliado nesta tarefa. Numa outra vertente, a conservação das cadernetas de campo, além do valor histórico, também auxilia na reconstituição do contexto geológico de amostras depositadas em museus e universidades, que, posteriormente, podem vir a ser estudadas por pesquisadores que não acompanharam o processo original de coleta e mapeamento. Um bom exemplo de patrimônio geológico ex situ são as cartas, mapas, cadernetas de campo e Fotografias do paleontólogo Kenneth Edward Caster, da Universidade de Cincinnati (Ohio, EUA), que realizou diversos trabalhos de campo no Brasil na década de 1940 (Ponciano 2013). Estes documentos representam um importante registro dos primórdios da paleontologia e geologia no Brasil. As cadernetas de campo de K.E. Caster já possibilitaram, em agosto de 2012, a descoberta de horizontes com concreções ferruginosas in situ da Formação Pimenteira na cidade de Picos. Infelizmente, o principal ponto de coleta de concreções fossilíferas de K.E. Caster é um morro localizado no centro de Picos, hoje em dia completamente ocupado por construções. Como este afloramento não é mais acessível para coleta de material e novas pesquisas (Figura 26), as informações sobre esta localidade só podem ser recuperadas a partir destas antigas cadernetas de campo, o que destaca a importância da conservação dos elementos ex situ do patrimônio geológico (Ponciano 2013).

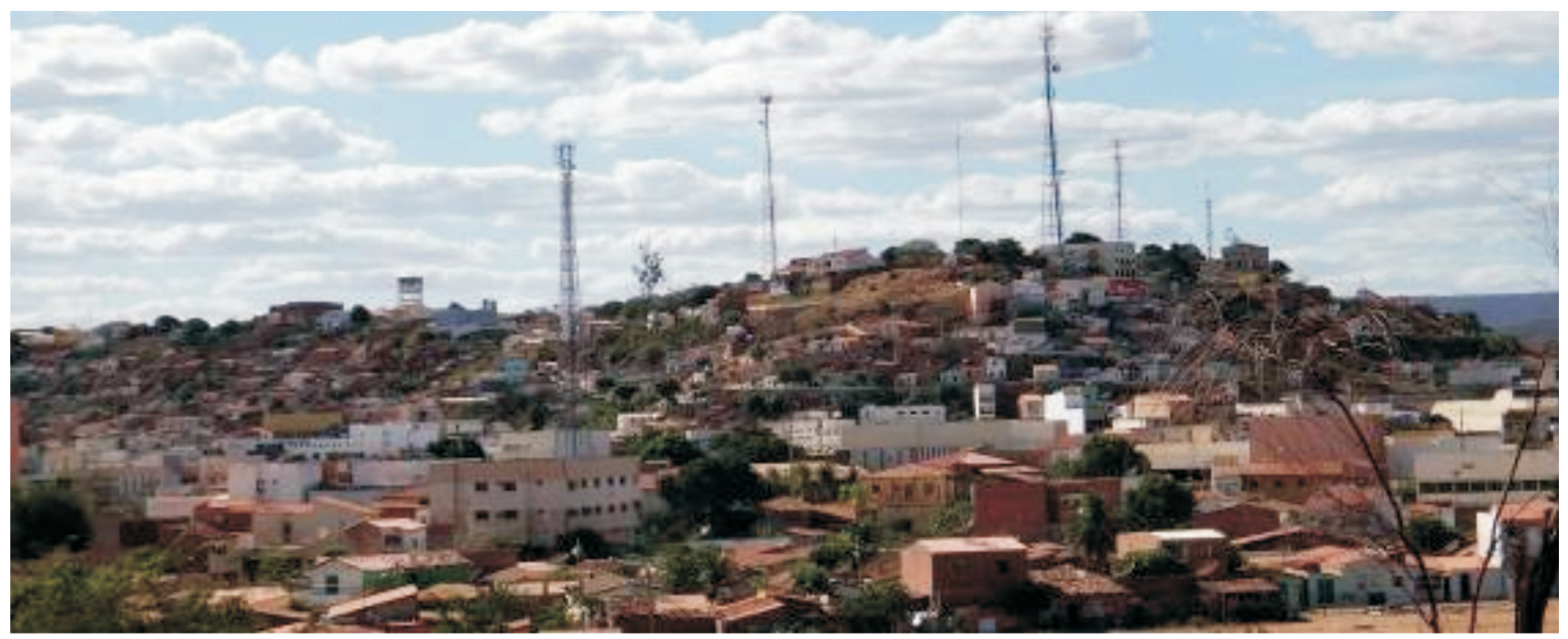

Figura 26 - Afloramento fossilífero da Formação Pimenteira estudado em 1947 por K.E. Caster, em Picos (PI), atualmente inacessível para novas pesquisas in situ.

\section{RESTAURO DO PATRIMÔNIO GEOLÓGICO}

Pelo exposto, fica claro que são necessárias análises prévias sobre os métodos de preservação dos geossítios contra o intemperismo, como a contenção de erosão, controle do fluxo de águas superficiais, consolidação de rochas, preenchimento de fraturas e fissuras, entre outros, antes da execução do restauro dos geossítios e elementos ex situ do patrimônio geológico.

Neste contexto de restauro do patrimônio geológico, entendido como as intervenções realizadas com a finalidade de recomposição sem descaracterização do valor intrínseco dos objetos, uma linha de pesquisa que deve ser desenvolvida é a de estudos sobre adequação dos métodos de restauro do patrimônio construído que possam ser aplicados aos geossítios.
Processos de restauro executados indevidamente podem piorar o estado de deterioração da superfície exposta das rochas, modificando ou danificando seu aspecto estético, pela perda de brilho e manchamentos, devido à interação das características intrínsecas das rochas com os agentes do meio ambiente e os procedimentos de fixação, limpeza e manutenção (Frascá 2003).

Cada caso deve ter sua análise e solução própria. Isto fica muito evidente quando se observa a Pedra do Índio, em Niterói, RJ (Figuras 27 e 28). Este monumento natural foi tombado como patrimônio estadual e encontra-se em franco processo de erosão. Uma decisão urgente a ser tomada é quanto à realização de uma intervenção para contenção do processo erosivo do mar ou, então, observar seu desabamento. 


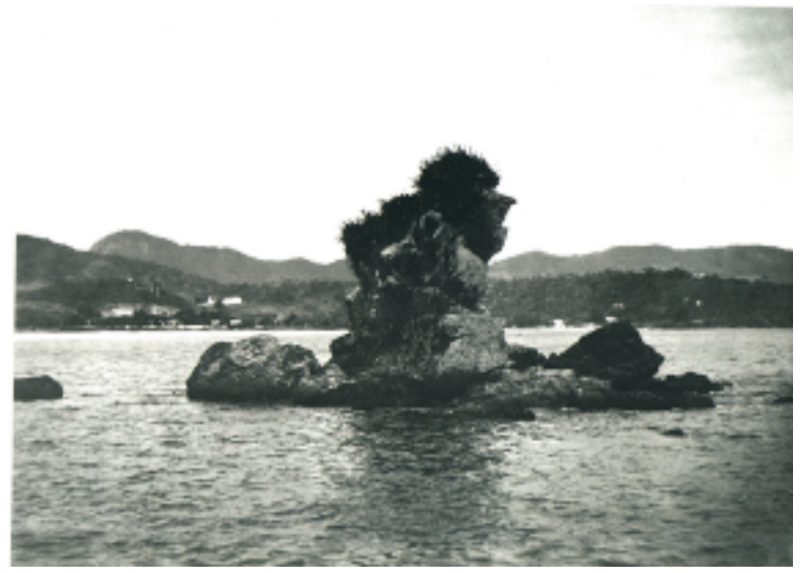

Figura 27 - Pedra do Índio em Niterói, tombada pelo Estado, por parecer do Instituto Estadual do Patrimônio Cultural INEPAC. Imagem de 1894 (acervo do Museu Histórico Nacional).

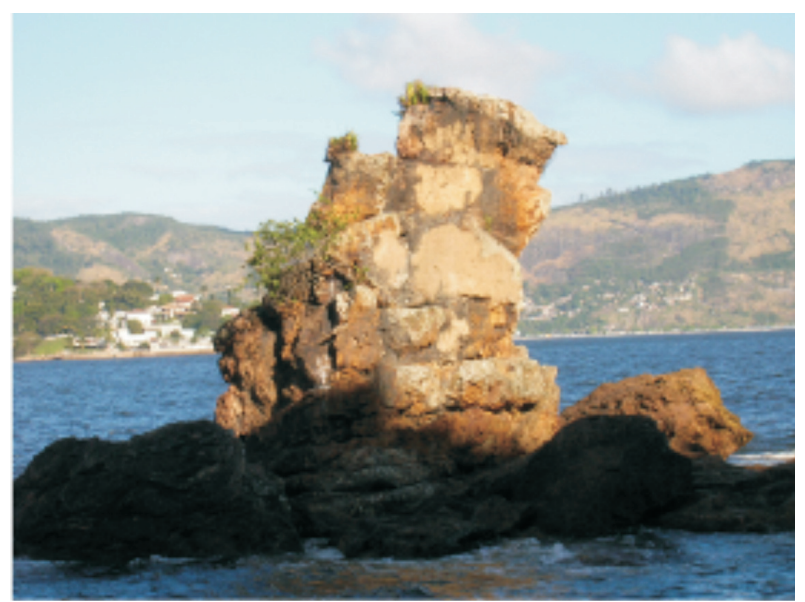

Figura 28 - Pedra do Índio em Niterói. Imagem de 2008 (Fotografia: Kátia Mansur).

O uso de escoras ou o preenchimento das fraturas podem ser soluções a serem consideradas. Em casos onde é necessária a contenção da erosão, um dos fatores a ser considerado é a composição da argamassa ou resina que poderia ser utilizada no preenchimento das áreas fraturadas, pois ela deve ser compatível com o tipo de rocha. Por exemplo, em uma rocha porosa, a utilização de argamassa inadequada pode levar à percolação de águas pluviais. Rachaduras, quebras, manchas e lascas também podem ser originadas pela cristalização de sais introduzidos na rocha pelo cimento utilizado nas argamassas (Smith 1999). As empresas de conservação que trabalham com patrimônio construído geralmente utilizam argamassas à base de cal hidráulica, que é um produto que endurece tanto no ar quanto na água.

O preenchimento de fraturas e fissuras seria particularmente útil em um geossítio como o de Souza (Figuras 29 a 33), onde a ameaça aos icnofósseis e petroglifos é iminente. Outra ocorrência recorrente é o crescimento de vegetação nestas fraturas e moldes, que além de dificultarem a visibilidade, aceleram o processo de destruição destes icnofósseis pelo intemperismo.

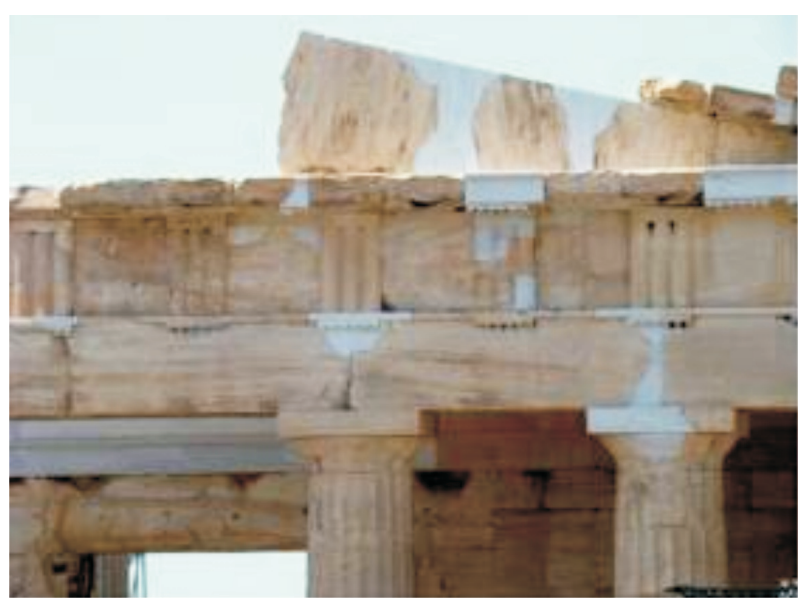

Figura 29 - Exemplos de restauração do patrimônio geológico. Restauro de patrimônio construído - Partenon de Atenas (Grécia), onde é nítida a diferença do mármore original e a restauração atual. 0 processo de restauração tem sido mais cuidadoso que as intervenções anteriores, que resultaram na intensificação das fissuras e fraturas e consequente destruição dos blocos originais de mármore. Atualmente as novas peças de mármore são fixadas com grampos de titânio e um tipo de cimento solúvel, metodologia que também poderia ser aplicada em geossítios (Fotografia: Luiza Ponciano, 2010).

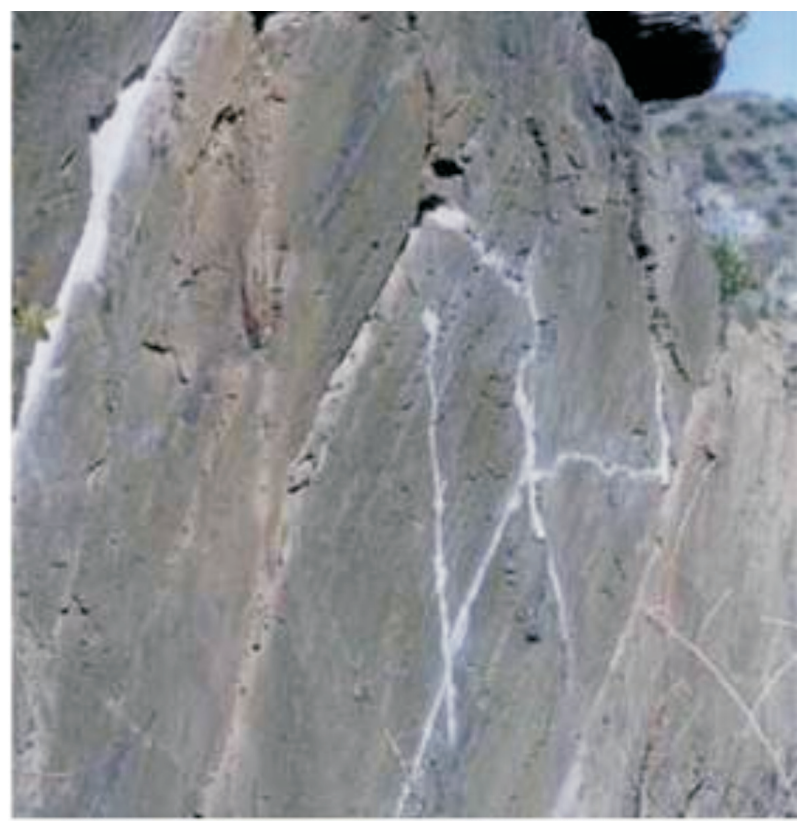

Figura 30 - Uso de argamassa como solução para preenchimento de fraturas: fraturas em rocha do sítio arqueológico de arte rupestre do Vale do Côa, em Portugal (fotografia extraída de Fernandes, 2008). 


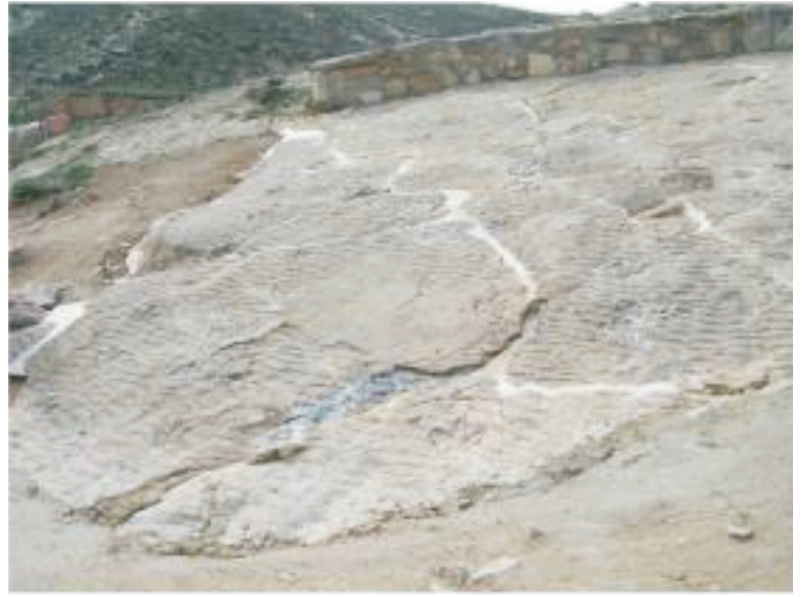

Figura 31 - Uso de argamassa como solução para preenchimento de fraturas: uso em sítio paleontológico em Aliaga, Espanha (Fotografia de Kátia Mansur, 2009).

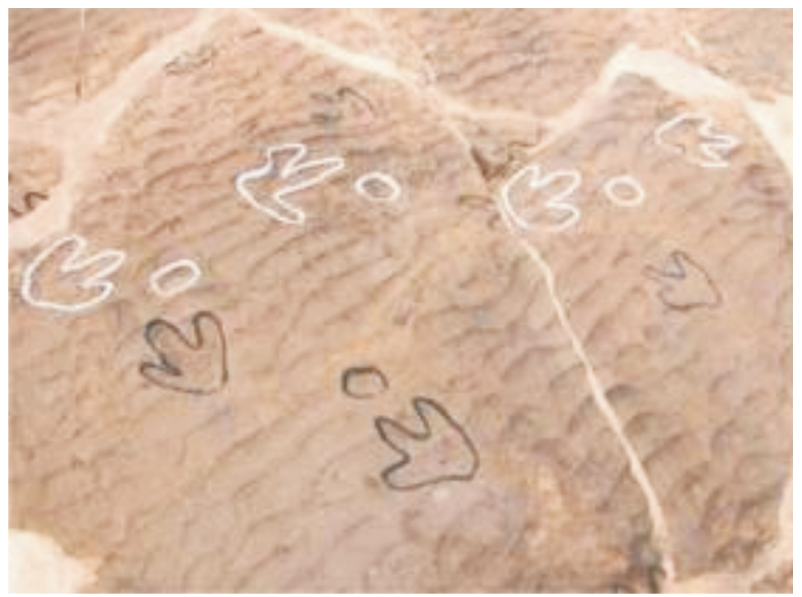

Figura 32 - Uso de argamassa como solução para preenchimento de fraturas: uso em sítio paleontológico em Aliaga, Espanha . É possível ver os detalhes do preenchimento com argamassa, além do contorno acentuado das pegadas, que causou um impacto desnecessário ao afloramento (Fotografia: José Brilha).

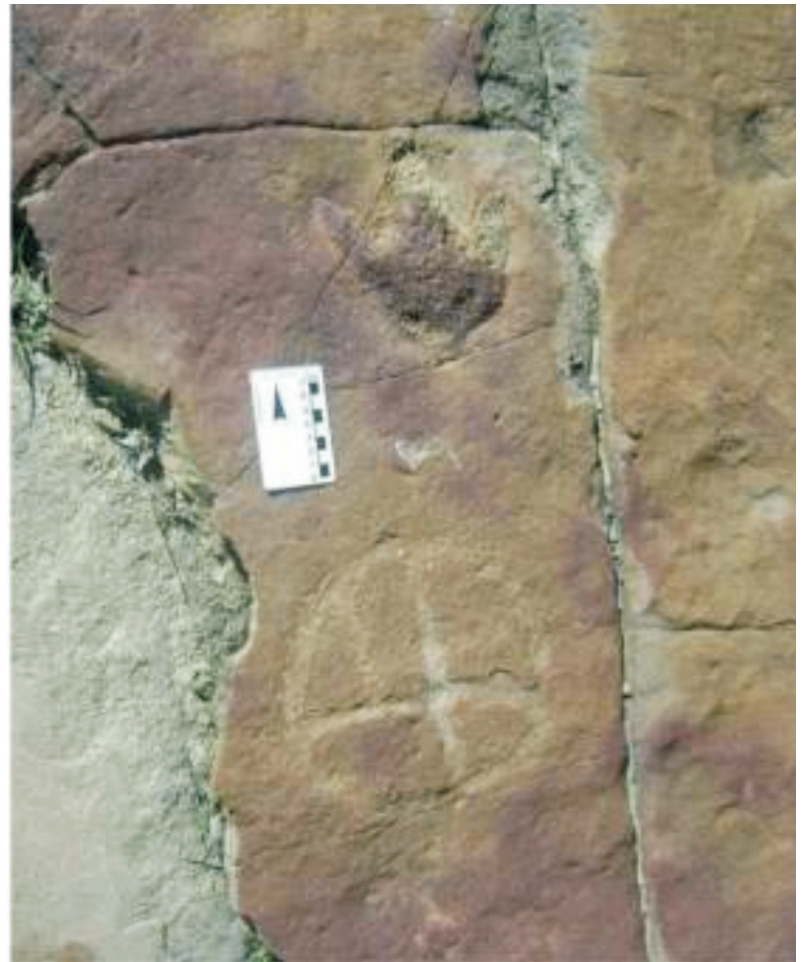

Figura 33 - Possível uso de argamassa como solução para preenchimento de fraturas: algumas pegadas em Sousa não estão dentro do território protegido pelo Parque dos Dinossauros, o que agrava ainda mais a situação dos geossítios. Estas amostras afloram em terreno particular e os proprietários não recebem incentivos para preservá-las. A pegada e o petroglifo atravessados pelas fraturas poderão ser facilmente destruídos pela erosão se não for realizada uma intervenção no local (Fotografia: Aline Castro, 2012).

O preenchimento de furos originados pela coleta de testemunhos também é outro método de restauro em geossítios, onde poderiam ser utilizados diferentes tipos de argamassa. Uma metodologia sugerida por MacFadyen (2011) é primeiramente preencher o espaço com outro testemunho de diâmetro ligeiramente menor ou com pequenos fragmentos da rocha, retirados de blocos rolados do mesmo tipo de rocha (nunca de material in situ). O espaço restante deve ser preenchido com argamassa e/ou resina adequadas para o tipo da rocha que está sendo restaurada. A parte superior do furo deve ser recoberta com o pedaço quebrado do testemunho que foi extraído, ou deve ser reproduzida a textura da superfície da rocha trabalhando a argamassa ou resina. No caso do uso de fragmentos de rocha, eles devem ser reduzidos para um tamanho pequeno e misturados à argamassa ou resina antes da aplicação no furo, para que o espaço seja completamente preenchido. 
A tentativa de restauração apresentada a seguir demonstra uma intervenção efetuada incorretamente (Figuras 34 e 35). Foi solicitado que o grupo de pesquisadores responsável pela coleta dos testemunhos em um geossítio clássico na costa oeste da Escócia retornasse ao local para restaurar a parte danificada. Além de não terem sido completamente preenchidos, os furos foram recobertos com um material de textura e coloração diferentes, que não foi resistente ao intemperismo em curto período de tempo. Como agravante, os fragmentos de rocha no interior dos furos foram coletados de calcários in situ, situados na zona de contato com a intrusão de onde foram removidos os testemunhos (MacFadyen 2011).

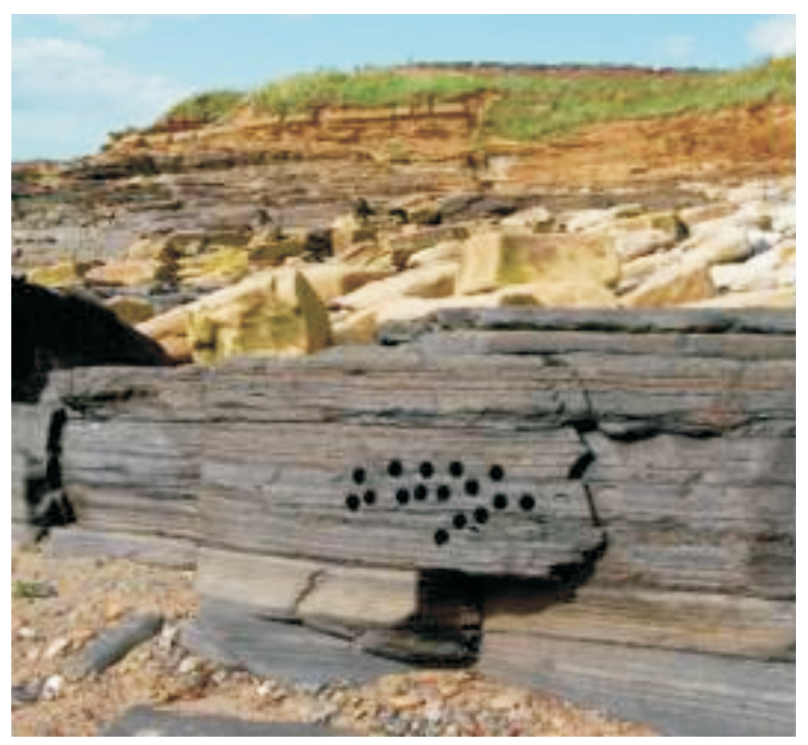

Figura 34 - Tentativa de restauração efetuada incorretamente em um geossítio clássico na costa oeste da Escócia (MacFadyen 2011).

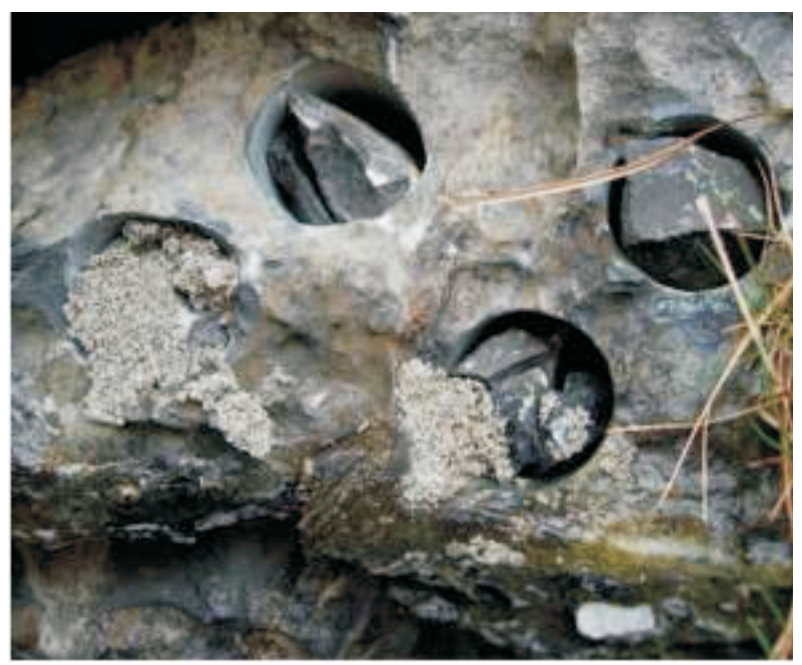

Figura 35 - Tentativa de restauração efetuada incorretamente em um geossítio clássico na costa oeste da Escócia (MacFadyen 2011).
Outro geossítio do Reino Unido (Wales) constitui um exemplo muito interessante de restauração de um afloramento modificado por ações antrópicas, visando conter o processo de erosão costeira e enchentes (Figuras 36 e 37). As autoridades locais constataram em 2006 a construção ilegal de um muro gabião de 110 metros de extensão, que cobriu cerca de 50 metros de um geossítio de especial interesse científico. Após uma longa disputa, em 2011 foi realizado o processo de restauração, quando as rochas do muro foram removidas e enterradas na praia, após acordo entre as autoridades locais e o dono da terra. As rochas foram enterradas na esperança de auxiliar a conter o processo erosivo, motivo da construção do muro pelo dono da terra (Roberts 2011).

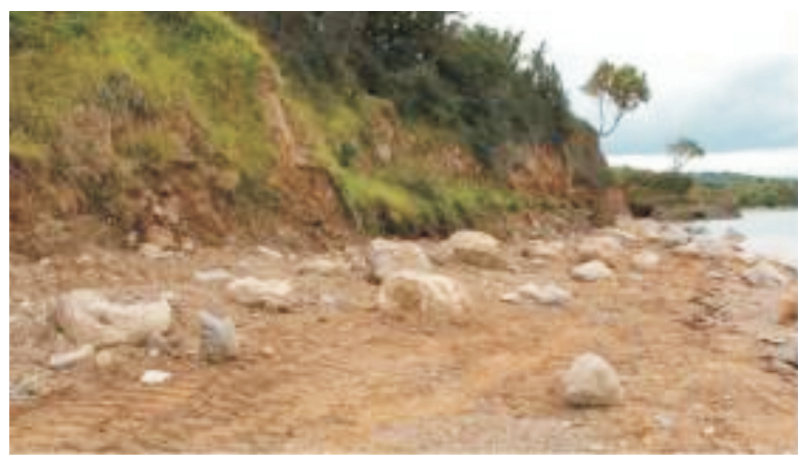

Figura 36 - Aparência do geossítio em 2011, após a remoção do muro gabião que estava cobrindo parte de um geossítio onde afloram tilitos que marcam um importante contato Pleistoceno/Quaternário.

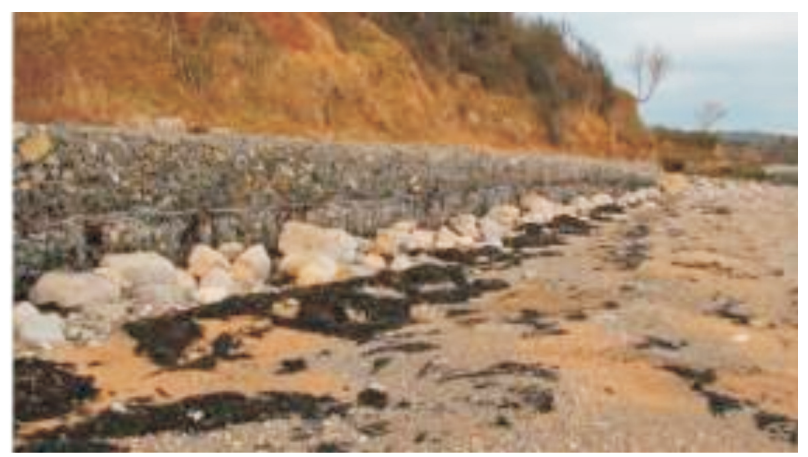

Figura 37 - A situação do local antes do processo de restauração, em 2006 (Roberts 2011).

Nos casos de restauro, uma importante questão a ser discutida é a reversibilidade das intervenções, conforme mencionado na proposta de Brandi (2002). Apesar dos materiais utilizados atualmente nestes tipos de procedimentos serem considerados reversíveis, todas as intervenções alteram os objetos enfocados. Mesmo que os vestígios materiais possam ser removidos após algum tempo, os efeitos da interação entre eles e o objeto não serão totalmente reversíveis. O intervalo de tempo em que terá de ser realizada a manutenção das intervenções e a quantidade de recursos alocados 
também devem ser considerados, para que seja viável manter as intervenções efetuadas do modo como foram originalmente planejadas (Fernandes, 2008).

A erosão é, sem dúvida, o processo natural que mais põe em risco o patrimônio geológico. Curiosamente, ela é responsável pela construção da maioria dos geomorfossítios porque tem papel central na escultura do relevo. Em alguns sítios onde a atuação da erosão é intensa assume-se a perda da paisagem, porque o processo é inexorável e a escala da intervenção necessária é muito grande (Mansur et al. 2012). A perda da paisagem antiga pode ser entendida como o ganho de uma nova paisagem. Este é o caso observado na llha do Francês, no Arquipélago de Sant'Anna, em Macaé. Nos lineamentos associados a falhas (brechas tectônicas), há uma intensificação do intemperismo que favorece a infiltração de água e a consequente instabilidade da encosta (Figuras 38 a 41). A praia teria se formado pelo recuo da encosta por movimentos de massa sucessivos no tempo. Este processo levará à divisão da ilha, uma vez que a erosão na vertente leste apresenta processo idêntico.

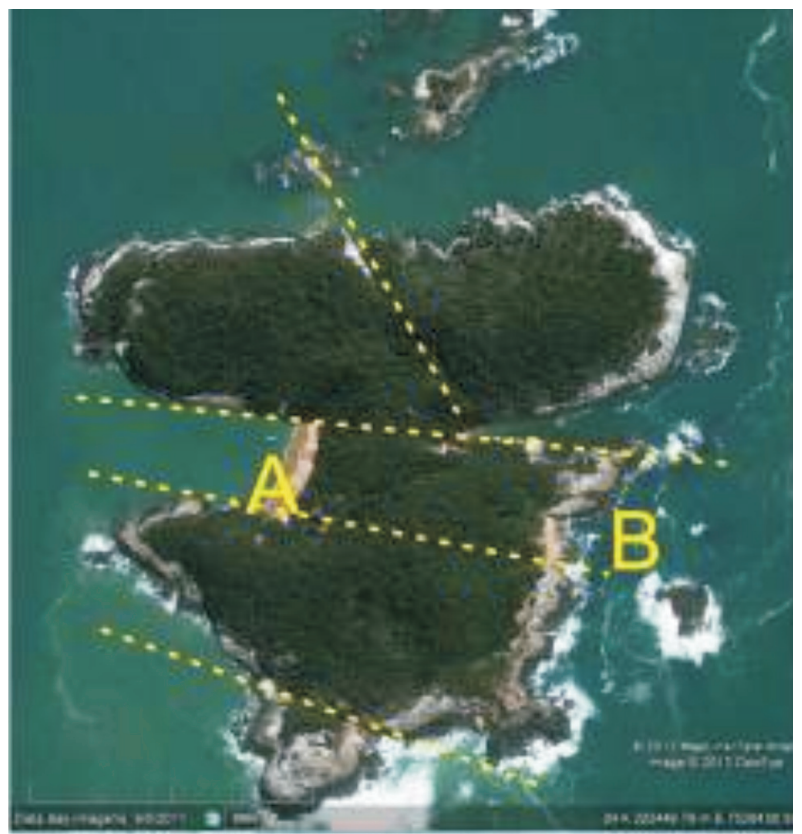

Figura 38 - Ilha do Francês, Arquipélago de Santana em Macaé, RJ. Imagem Google Earth com os lineamentos. A e B, representam vistas das praias.

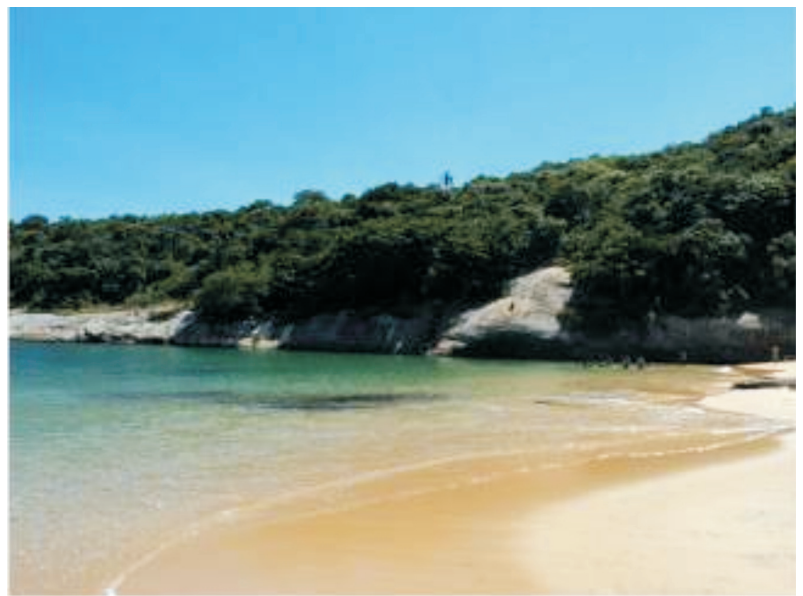

Figura 39 - Ilha do Francês, Arquipélago de Santana em Macaé, RJ. Vista da praia na porção A da llha (Figura 38).

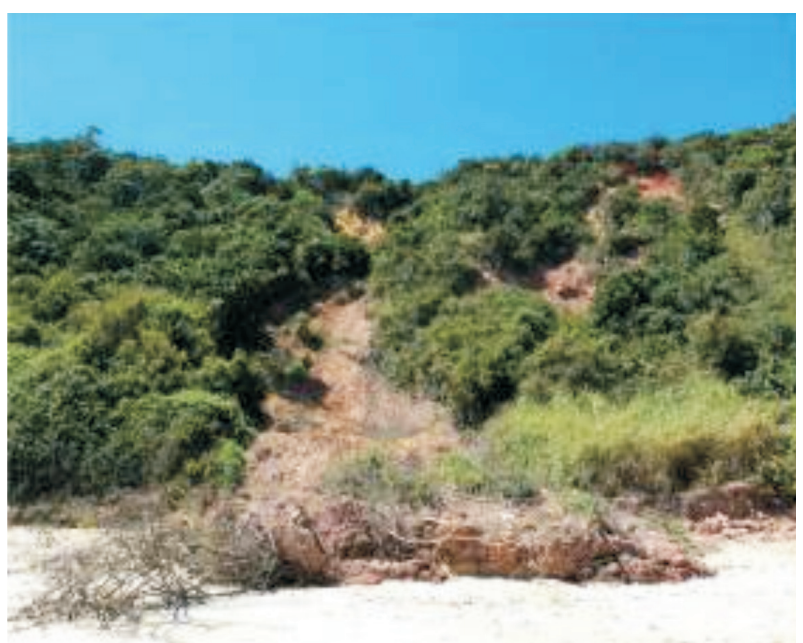

Figura 40 - Ilha do Francês, Arquipélago de Santana em Macaé, RJ. Movimento de massa no ponto A e B (esquerda e direita Figura 38).

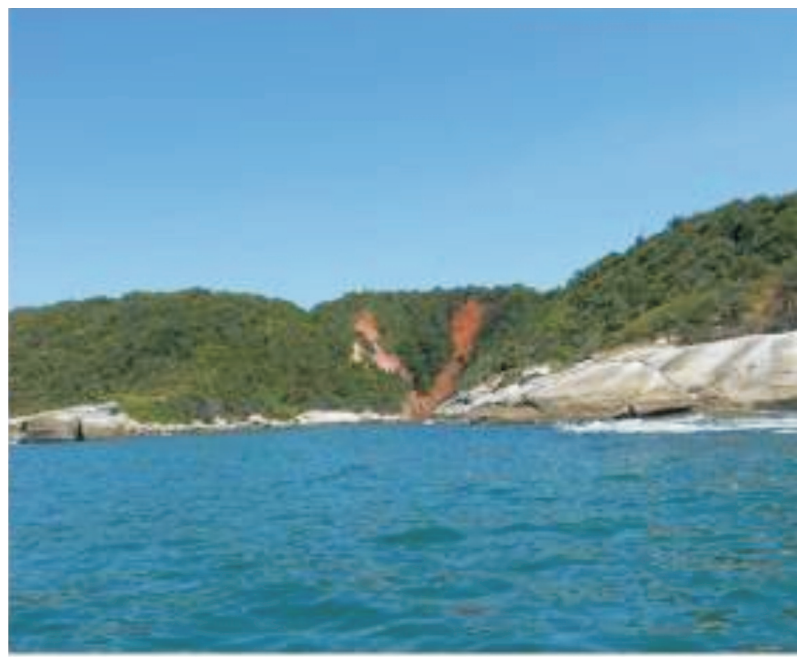

Figura 41 - Ilha do Francês, Arquipélago de Santana em Macaé, RJ. Movimento de massa no ponto A e B (esquerda e direita Figura 38). 
A llha do Francês é um exemplo de construção da paisagem, onde se constata que a atuação de processos erosivos considerados como visualmente desagradáveis podem condicionar a formação de locais de grande beleza cênica. A beleza do processo geológico se destaca, apesar da aparente feiúra da cicatriz na encosta (Mansur et al. 2012).

Vale, ainda, destacar o uso geoturístico, científico e educacional que pode ser dado a sítios degradados pela mineração, sem que restauro seja realizado. Exemplos como os de Ametista do Sul (RS) e o Parque Paleontológico de São José de Itaboraí, RJ devem ser destacados (Figuras 42 e 43).

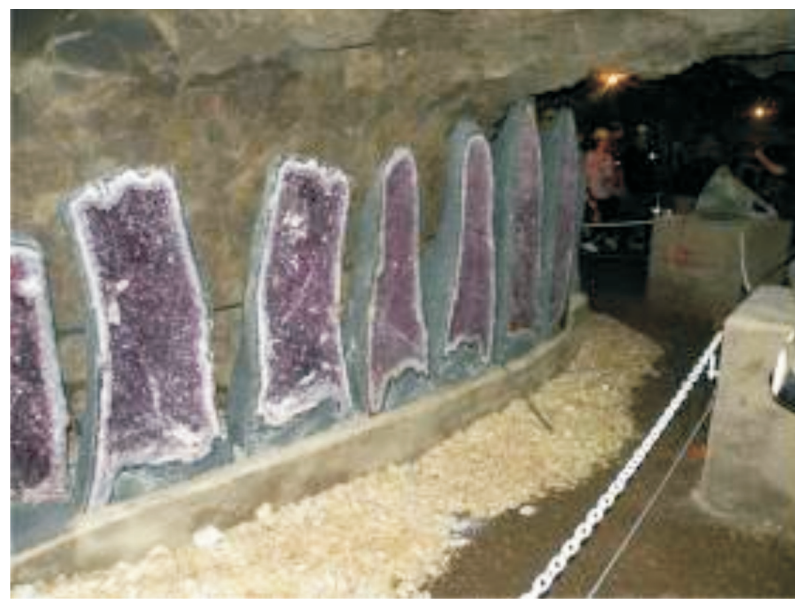

Figura 42 - Usos para áreas degradadas. Ametista do Sul, RS: área de visitação geoturística com apresentação de materiais e processos utilizados na lavra (Fotografia: Ismar Carvalho, 2010).

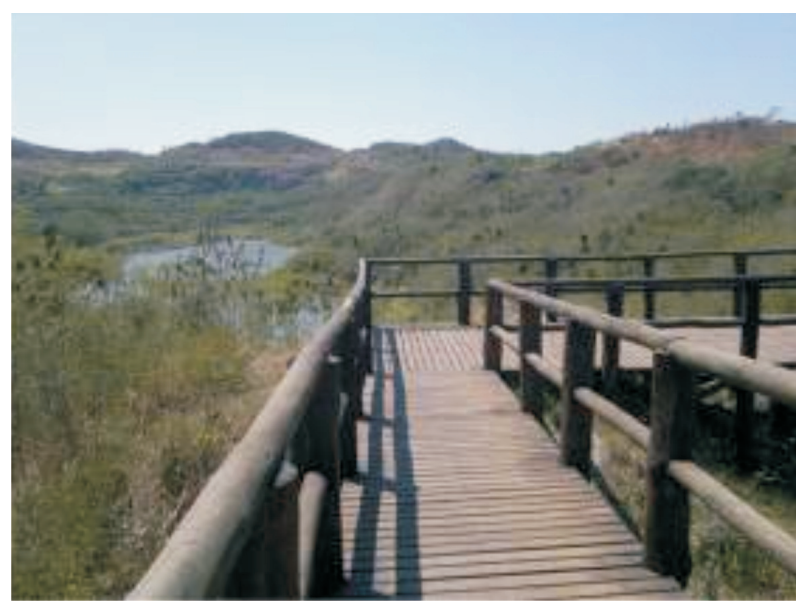

Figura 43 - Usos para áreas degradadas. Parque Paleontológico de São José de Itaboraí, RJ: com o fim da vida útil da jazida, a área foi abandonada pela empresa mineradora. Hoje, um novo uso está sendo viabilizado para a área na forma de geoturismo (Fotografia: Kátia Mansur, 2012).

\section{EDUCAÇÃO PATRIMONIAL}

A Educação Patrimonial é uma ferramenta pedagógica desenvolvida pela área cultural, mas que é perfeitamente adaptável como proposta de trabalho nas localidades onde ocorrem os geossítios, no intuito de complementar a grade de ensino e as atividades geoturísticas (Castro \& Machado 2011). Entende-se por Educação Patrimonial o processo permanente e sistemático de trabalho educacional enfocando o patrimônio como fonte primária de conhecimento e de enriquecimento individual e coletivo, utilizando objetos e/ou expressões como ponto de partida para desenvolver atividades pedagógicas, observando-os, questionando-os e explorando nos aspectos possíveis e traduzindo-os em conceitos e conhecimento (Grunberg 2000). Esse processo é muito útil para a preservação do patrimônio geológico por dois principais motivos. O primeiro deles é o investimento na sua salvaguarda. Uma vez que a população local passa a se identificar e a compreender a importância daqueles elementos da geodiversidade como patrimônio, ela irá desejar e incentivar a sua proteção. Na ausência do poder público, depredações e vandalismos poderão ser coibidos pela população local. O segundo motivo é o compromisso social que todos os cientistas devem ter. Com a proposta da educação patrimonial há um retorno para a comunidade, transmitindo o conhecimento que foi construído através dos geossítios (Souza 2006; Castro \& Machado 2011).

Nesta linha, destacam-se alguns projetos sistemáticos de popularização da geologia que têm sido instituídos no Brasil, como os Caminhos Geológicos do Rio de Janeiro (2001), Sítios Geológicos e Paleontológicos do Paraná (2003), Caminhos Geológicos da Bahia (2003), Monumentos Geológicos do Rio Grande do Norte (2006) e Monumentos Geológicos de São Paulo (2009). Em geral, baseiam-se em iniciativas ligadas ao Geoturismo e Geoconservação, especialmente por meio de implantação de painéis interpretativos (Piekarz \& Liccardo 2006; Cunha et al. 2006, Nascimento et al. 2007; Mansur \& Nascimento 2007).

Estas iniciativas podem inverter a tendência geral ainda vigente em nosso país de tentar retirar a maior quantidade possível de elementos da geodiversidade de seu lugar de origem, com o objetivo de salvá-los da destruição em lugares ermos e com uma população que desconhece a sua importância científica, didática e patrimonial. Um projeto que pode auxiliar na conservação in situ dos geossítios é o GEOSSIT, um banco de dados da CPRM destinado ao inventário, qualificação e valoração quantitativa de geossítios brasileiros (http://www.cprm.gov.br/geossit/geossitios), sendo livre consulta e operado por meio de uma base de dados específica do Sistema GEOBANK da CPRM. Também são muito relevantes os trabalhos publicados pela SIGEP (Comissão Brasileira de Sítios Geológicos e 
Paleobiológicos: http://sigep.cprm.gov.br/sitios.htm) e o projeto G e o p a r q u e s : http://www.cprm.gov.br/publique/cgi/cgilua.exe/sys/st art.htm?sid=134).

Atualmente, a necessidade de um retorno do conhecimento científico para a população do local onde são coletados os fósseis é cada vez mais difundida. Acredita-se que somente através da inclusão da comunidade local em projetos de educação patrimonial e geoturismo (com a instalação de museus, parques, centros de pesquisa e outras formas de geração de trabalho e renda), a conservação do patrimônio geológico in situ poderá ser concretizada em um país com as dimensões e problemas sociais do tamanho do Brasil (Ponciano et al. 2011).

A realização de programas de educação patrimonial também é fundamental para combater ameaças como o geovandalismo e outros danos antrópicos ao patrimônio. Em locais de visitação turística, um projeto especial de interpretação do geossítio deve ser elaborado para buscar uma melhor relação entre o visitante e a preservação do patrimônio. Entende-se que os aspectos funcionais e estéticos de um sítio devem ser desenvolvidos em toda a sua potencialidade, portanto diversos profissionais devem ser envolvidos nos projetos, como engenheiros, geógrafos, arquitetos, biólogos, museólogos e turismólogos, além de geólogos e paleontólogos, obviamente. A inclusão da disciplina de geoconservação nos cursos universitários que formam os profissionais citados acima também contribuiria para a difusão da importância da conservação do patrimônio geológico.

\section{COMENTÁRIOS FINAIS}

A análise preliminar dos estudos de caso apresentados indica que devem ser direcionados mais esforços na proposição e experimentação de materiais e técnicas de conservação e restauração voltadas para o patrimônio geológico, assim como para a compreensão de tudo o que está associado com as intervenções, como as causas e efeitos dos processos naturais e antrópicos que interferem no local. Por exemplo, alguns trabalhos de arqueologia realizam um monitoramento topográfico dos afloramentos e das vertentes onde estes se encontram, além da análise detalhada de fatores sísmicos, geomorfológicos e climáticos da região.

A efetividade da conservação do patrimônio geológico in situ dependerá da implantação eficaz de uma ampla estrutura de fiscalização, manutenção e de atividades didáticas e recreativas contínuas, que devem ser reavaliadas e adaptadas segundo os tipos e graus de problemas da área e de participação da população do entorno e visitantes dos geossítios. As atividades didáticas e recreativas e o monitoramento das instalações e da infraestrutura devem ser frequentes para evitar o abandono dos sítios pela comunidade e pelos visitantes, pois se o local não estiver em boas condições de visitação (afloramento visível aos visitantes, com os acessos e infraestrutura limpos e bem conservados, por exemplo) as pessoas irão se deslocar para outras regiões.

O restrito conhecimento geológico e paleontológico da maioria da população brasileira, derivado da precária educação formal e informal na área das geociências, tem relação direta com a carência de medidas de conservação e restauração do patrimônio geológico. Grande parte dos professores dos diferentes níveis de ensino não foi apresentada nem aos conteúdos básicos de geologia e paleontologia durante mais de uma década e meia de ensino formal. Enquanto estas disciplinas não são incluídas nos currículos escolares em todos os níveis de educação formal, projetos de educação patrimonial nas comunidades próximas aos sítios paleontológicos, exposições em museus, publicação de textos de divulgação em sites e revistas, palestras e cursos professores são alternativas para auxiliar na divulgação das geociências para a sociedade.

Finalmente, é muito importante o desenvolvimento de uma visão patrimonial em todos aqueles que trabalham direta ou indiretamente com os geossítios brasileiros, independentemente de sua formação acadêmica. O nosso patrimônio geológico está sujeito a diversos tipos de ameaças, e em muitos casos os próprios geocientistas são os responsáveis por sua destruição. Portanto, sugere-se que antes da realização da coleta de material em trabalhos de campo, a distribuição e o modo de ocorrência das concentrações fossilíferas e de outros elementos da geodiversidade sejam avaliadas de acordo com as peculiaridades dos depósitos e os objetivos dos estudos, a fim de evitar a retirada excessiva de material in situ dos geossítios. Acredita-se que a conservação dos geossítios in situ poderia ser mais difundida e aprimorada através da elaboração de um código de conduta para trabalhos de campo em Geologia e Paleontologia no Brasil. 


\section{Referências}

AIRES-BARROS, L. 1991. Alteração e alterabilidade de rochas. Universidade Técnica de Lisboa, Instituto Nacional de Investigação Científica, Lisboa, 384p.

ASSUNÇÃO, P. de. 2003. Patrimônio. Edições Loyola, São Paulo, 108p.

BENSUSAN, N. 2006. Conservação da biodiversidade em áreas protegidas. Editora FGV, Rio de Janeiro, 176p.

BOONCHAI, N.; GROTE, P.J.; JINTASAKUL, P. 2009. Paleontological parks and museums and prominent fossil sites in Thailand and their importance in the conservation of fossils. In: LIPPS, J.H. \& GRANIER, B.R.C. (eds.) PaleoParks - The protection and conservation of fossil sites worldwide. Carnets de Géologie - Notebooks on Geology, Chapter 07, 7895p.

BRAGA, M. (Org.) 2003. Conservação e Restauro: madeira, pintura sobre madeira, douramento, estuque, cerâmica, azulejo, mosaico. Ed. Rio, Rio de Janeiro, 152p.

BRANDI, C. 2000. Teoria de la Restauración. Alianza Ed., Madri, 149p.

BRASIL. 1942. Decreto-lei no 4146 de 4 de março de 1942.

D i s p o n í v e I

e $\mathrm{m}$ :

http://www.dnpm.gov.br/conteudo.asp?IDSecao=6 7\&IDPagina=84\&IDLegislacao=2. Acesso em dezembro de 2010.

BRILHA, J.B. 2005. Património Geológico e Geoconservação: A Conservação da Natureza na sua Vertente Geológica. Palimage Editores, Braga, 190 p.

CAPUTO, M.V.; PONCIANO, L.C.M.O. 2010. Pavimento Estriado de Calembre, Brejo do Piauí - Registro de geleiras continentais há 360 milhões de anos no Nordeste do Brasil. In: Winge, M.; Schobbenhaus, C.; Souza, C.R.G.; Fernandes, A.C.S.; Berbert-Born, M.; Sallun Filho, W.; Queiroz, E.T. (Eds.). Sítios Geológicos e Paleontológicos do Brasil, v. 3, 12p. Disponível em http://sigep.cprm.gov.br/sitio052/sitio052.pdf.

CASTRO, A. R. de S. F. de; MACHADO, D. M. da C. 2011. A percepção patrimonial da população ao entorno do Parque Paleontológico de São José de Itaboraí. I Simposio de Geoparque y Geoturismo en Chile. Melipeuco, Chile. Actas del I Simposio de Geoparque y Geoturismo en Chile. v.1, p.42-45.

CHOAY, F. 2001. A alegoria do patrimônio. Editora UNESP, São Paulo, $282 \mathrm{p}$.

CUNHA, E.M.S.; NESI, J.R.; NASCIMENTO, M.A.L. 2006. Projeto Monumentos Geológicos do Rio Grande do Norte: a divulgação e conservação do patrimônio geológico potiguar. In: Congresso Brasileiro de Geologia, 43, 2006, Aracaju/SE, Anais, Aracaju: Sociedade Brasileira de Geologia. p. 90.

CURY, I. (Org.). 2000. Cartas Patrimoniais. 2.ed., IPHAN, Rio de Janeiro, 384p.

DELPHIM, C.F.M. 2004. Patrimônio natural no Brasil. Rio de Janeiro: IPHAN, 2004, 20p.
FEDONKIN, M.A.; IVANTSOV, A.Y.; LENOV, M.V.; LIPPS, J.H.; SEREZHNIKOVA, E.A.; MALYUTIN, E.I.; KHAN, Y.V. 2009. Paleo-piracy endangers Vendian (Ediacaran) fossils in the White Sea - Arkhangelsk region of Russia. In: LIPPS J.H. \& GRANIER B.R.C. (eds.), PaleoParks - The protection and conservation of fossil sites worldwide. Carnets de Géologie/Notebooks on Geology, Chapter 09.

FERNANDES, A.P.B. 2008. Limites de intervenção na conservação de superfícies de arte rupestre: $O$ caso específico dos afloramientos gravados do Vale do Côa. In: BEHRMANN, R.B. (ed) Arte Prehistórico al aire libre en el Sur de Europa, Junta de Castilla y León, Consejería de Cultura y Turismo, p.437-489.

FLORES, G. 2005. Caderno do Professor. Calendário Museológico. Superintendência de Museus do Estado de Minas Gerais. Disponível em: < h t t p : / / w w w. conserva c a o restauracao.com.br/por_que_preservar.pdf $>$. Acesso em: 12 abr. 2011.

FONSECA, M. C. L.. 2005. O Patrimônio em processo: trajetória da política federal de preservação de preservação no Brasil. Rio de Janeiro; UFRJ: IPHAN. 2a edição, 278p.

FRASCÁ, M.H.B.O. 2003. Estudos experimentais de alteração acelerada em rochas graníticas para revestimento. Tese (Doutorado), Instituto de Geociências, Universidade de São Paulo, São Paulo, $281 p$.

GONÇALVES, J. R.S. 2000. A Retórica da Perda: os discursos do patrimônio cultural no Brasil. Rio de Janeiro: Editora UFRJ; IPHAN, 2a edição, 200p.

GRUNBERG. E. 2000. Educação Patrimonial: Utilização dos Bens Culturais como Recursos Educacionais". In: Museologia Social. Porto Alegre, Secretaria Municipal de Cultura, 95-110p.

LIMA, D. F. C. 1997. Social Memory and Museum Institution: Thinking about the (re)presentation of Cultural Heritage. In: XIXth Annual Conference of ICOFOM/International Comitee for Museology. 1997, Paris, p. 202-11.

MACFADYEN, C. 2007. Coreholes: a widespread problem. Earth heritage, 28, p. 17.

MACFADYEN, C. 2011. Irresponsible coring: new guidelines and establishing a methodology for outcrop restoration. Earth heritage, 36, p. 11-12.

MANSUR, K.L.; NASCIMENTO, V.M.R. Popularización del Conocimiento Geológico: Metodología del Proyecto Caminhos Geológicos . Enseñanza de las Ciencias de la Tierra, v. 15, p. 77-84, 2007.

MANSUR, K. L. Projetos Educacionais para a Popularização das Geociências e para a Geoconservação. Geologia USP. Publicação Especial, v. 5, p. 63-74, 2009. 
MANSUR, K. L. Algumas reflexões sobre os métodos de conservação do Patrimônio Geológico e Paleontológico. In: XXII Congresso Brasileiro de Paleontologia, 2011, Natal. Atas do XXII CBP. Natal: Sociedade Brasileira de Paleontologia, 2011. v. único. p. 115-118.

MANSUR, K. L.; ALMEIDA, M. S.; PRESSI, L. F.; Garin, Y.; VAZ, M.; CARNEIRO, N. M.. A. 2012. Conservação do Geossítio da Ilha do Francês, em Macaé / RJ: Reflexões sobre a Beleza de um Processo Geológico. In: 46 Congresso Brasileiro de Geologia, 2012, Santos. Anais do 46 Congresso Brasileiro de Geologia. Santos: SBG - Sociedade Brasileira de Geologia, v. 1.

NASCIMENTO, Marcos Antônio Leite do; RUCHKYS, Úrsula Azevedo; MANTESSONETO,Virgínio. Geoturismo: um novo segmento do turismo no Brasil. Global Tourism, São Paulo, v. 3, n. 2, 2007.

PAGÈS, J.S. 2009. The GeoPark of Haute-Provence, France: Geology and palaeontology protected for sustainable development. In: LIPPS J.H. \& GRANIER B.R.C. (eds.). PaleoParks - The protection and conservation of fossil sites worldwide. Carnets de Géologie/Notebooks on Geology, Chapter 03.

PIEKARZ, G. P.; LICCARDO, A. Programa Sítios Geológicos e Paleontológicos do Paraná - situação atual e tendências. In: CONGRESSO BRASILEIRO DE GEOLOGIA, 43., 2006, Aracaju. Anais... Aracaju: SBGBA/SE, 2006, p. 89-89.

PONCIANO, L.C.M.O. 2013. Tafocenoses mesodevonianas da Bacia do Parnaíba no estado do Piauí: Análise tafonômica, paleoambiental e patrimonial. 110 f. Tese (Doutorado em Geologia), Instituto de Geociências, Universidade Federal do Rio de Janeiro, Rio de Janeiro, 2013.

PONCIANO, L.C.M.O.; CASTRO, A.R.S.F.; FONSECA, V.M.M.; MACHADO, D.M.C. 2012. Tafocenoses da Formação Pimenteira, Devoniano da Bacia do Parnaíba, Piauí: Mapeamento, Inventário e Relevância Patrimonial. Anuário do Instituto de Geociências da UFRJ, v.35, p.05-27.

PONCIANO, L.C.M.O.; CASTRO, A.R.S.F.; MACHADO, D.M.C.; FONSECA, V.M.M.; KUNZLER, J. 2011. Patrimônio Geológico-Paleontológico in situ e ex situ: Definições, vantagens, desvantagens e estratégias de conservação. In: Carvalho, I.S. et al. (eds.). Paleontologia: Cenários de Vida. Editora Interciência, v. 4, p. 853-869.

PONCIANO, L.C.M.O.; FONSECA, V.M.M.; FERNANDES, A.C.S.; MACHADO, D.M.C.; SOUZA, A.R. 2010. Afloramento Fossilífero de Oiti, Bacia do Parnaíba, PI Registro de um mar devoniano no Nordeste do Brasil. In: Winge,M.; Schobbenhaus,C.; Souza,C.R.G.; Fernandes,A.C.S.; Berbert-Born,M.; Sallun filho,W.; Queiroz,E.T. (Edit.). Sítios Geológicos e Paleontológicos do Brasil (SIGEP), v. 3.
REYS, A.C.; DEL LAMA, E.A.; DEHIRA, L.K. 2008. Monumentos da cidade de São Paulo: formas de alteração e conservação. Revista CPC, São Paulo, n. 5, p. 93-122.

ROBERTS, R. 2011. Re-exposed: important coastal section cleared of gabions. Earth heritage, 36, p. 9-10.

SCHEINER, T. C. M. 2006. Sob o signo do patrimônio: museologia e identidades regionais. In: COSTA, H., DECAROLIS, N., SCHEINER, T. (Coord.) Museologia e o Patrimônio Regional / Museología y el Património Regional. Encuentro del Subcomité Regional del ICOFOM para América Latina y el Caribe (12). Encontro do Subcomitê Regional do ICOFOM para a América Latina e o Caribe (12). Salvador, Bahia, Brasil. Tacnet Cutural Ltda., Rio de Janeiro, [não paginado].

SMITH, M. R. 1999. Stone: building stone, rock fill and armourstone in construction. London: Geological Society of Engineering Geology, Special Publication n.16, 478p.

SOUZA, A.R. de, 2006. O conteúdo fossilífero da Formação Pimenteira como parte do Patrimônio Geológico brasileiro. Rio de Janeiro: Unirio / Escola de Museologia, Monografia. 199p.

SOUZA, A.R.; MACHADO, D.M.C.; PONCIANO, L.C.M.O.; FARIA, A.C.G.; VIEIRA, A.C.M. \& PINTO, F.M. 2007. Geoconservação: a preservação e valorização do patrimônio geológico. In: Carvalho, I.S. et al. (Org.). Paleontologia: Cenários de Vida. 1 ed.: Editora Interciência, v. 2, p. 79-88.
Manuscrito ID 31871

Submetido em maio de 2013 Aceito em julho de 2013 